\title{
WestVirginiaUniversity
}

THE RESEARCH REPOSITORY @ WVU

Graduate Theses, Dissertations, and Problem Reports

2018

\section{The Life And Work Of Barbara Nissman}

\author{
Giuliana Paola Contreras Ampuero \\ West Virginia University, gpcontreras@mix.wvu.edu
}

Follow this and additional works at: https://researchrepository.wvu.edu/etd

Part of the Music Performance Commons

\section{Recommended Citation}

Contreras Ampuero, Giuliana Paola, "The Life And Work Of Barbara Nissman" (2018). Graduate Theses, Dissertations, and Problem Reports. 3749.

https://researchrepository.wvu.edu/etd/3749

This Dissertation is protected by copyright and/or related rights. It has been brought to you by the The Research Repository @ WVU with permission from the rights-holder(s). You are free to use this Dissertation in any way that is permitted by the copyright and related rights legislation that applies to your use. For other uses you must obtain permission from the rights-holder(s) directly, unless additional rights are indicated by a Creative Commons license in the record and/ or on the work itself. This Dissertation has been accepted for inclusion in WVU Graduate Theses, Dissertations, and Problem Reports collection by an authorized administrator of The Research Repository @ WVU.

For more information, please contact researchrepository@mail.wvu.edu. 
THE LIFE AND WORK OF BARBARA NISSMAN

\author{
Giuliana Paola Contreras Ampuero
}

A Doctoral Research Project submitted to the College of Creative Arts

at

West Virginia University

In partial fulfillment of the requirements for the degree of

Doctor of Musical Arts

in

Collaborative Piano

Lucy Mauro, DMA, Chair and Research Advisor
Peter Amstutz, DMA
William Haller, DMA
Mikylah Myers, DMA
Deborah Janson, PhD

School of Music

Morgantown, West Virginia

2018

Keywords: Barbara Nissman, American concert pianist, Alberto Ginastera, Béla Bartók, Franz Liszt, Sergei Prokofiev. 


\section{ABSTRACT \\ THE LIFE AND WORK OF BARBARA NISSMAN}

\section{Giuliana Paola Contreras Ampuero}

This research paper focuses on the life and work of American concert pianist Barbara Nissman (b. 1944). Her extensive work as a performer, writer, lecturer and guest clinician makes Nissman one of the most accomplished artists of our time. This paper is the first comprehensive look at Nissman's career and her diverse contributions to piano study and performance as a leading expert on the piano music of Alberto Ginastera (1916-1983), Sergei Prokofiev (18911953), Béla Bartók (1881-1945), and Franz Liszt (1811-1886). As an overview of Nissman’s life and career, this paper provides both a thorough presentation of Nissman's contributions and serves as a resource for presenting her work to a wider audience. The paper includes a biography of Nissman, supported by her own personal and professional accounts; separate chapters on the piano music of Alberto Ginastera, Béla Bartók, Franz Liszt and Sergei Prokofiev with Nissman's remarks on each composer's compositional language along with study and performance suggestions; a revealing interview with Nissman discussing her professional career, experience working with prominent musicians, and advice for the next generation of pianists; and a detailed list of Nissman's recordings and publications. 


\section{ACKNOWLEDGMENTS}

First and foremost, I would like to express my deepest gratitude to pianist Barbara Nissman for her vital assistance in writing this research paper. I am grateful for her dear friendship and for her desire to share her artistry and knowledge. I would like to especially thank my research advisor, mentor, and teacher, Dr. Lucy Mauro, for her continuous support, guidance and encouragement, not only on this project, but throughout my doctoral studies. Also, I would like to thank my committee members, Dr. Peter Amstutz, Dr. William Haller, Dr. Mikylah Myers, and Dr. Deborah Janson for their advice, support and knowledge. Lastly, I would like to sincerely thank my husband and family for their constant love and support.

Giuliana Contreras

November, 2018 


\section{TABLE OF CONTENTS}

ABSTRACT

ACKNOWLEDGMENTS iii

TABLE OF CONTENTS iv

LIST OF FIGURES $\quad$ v

CHAPTER I - Biography of Barbara Nissman 1

CHAPTER II - Barbara Nissman on Alberto Ginastera’s Piano Music 18

CHAPTER III - Barbara Nissman on Béla Bartók’s Piano Music 29

CHAPTER IV - Barbara Nissman on Franz Liszt’s Piano Music 37

CHAPTER V - Barbara Nissman on Sergei Prokofiev’s Piano Music 45

CHAPTER VI - Interview with Barbara Nissman $\quad 56$

$\begin{array}{lc}\text { CHAPTER VII - Conclusion } & 68\end{array}$

SELECTED DISCOGRAPHY

SELECTED WRITINGS AND EDITIONS 181

$\begin{array}{ll}\text { BIBLIOGRAPHY } & 82\end{array}$ 


\section{LIST OF FIGURES}

Figure 1. Barbara Nissman performing at a John Deere factory. $\quad 8$

Figure 2. Barbara Nissman performing at the first Gracht Concert in Amsterdam. 10

Figure 3. Barbara Nissman at the Walden Woods Project Fundraising Concert in New York City. $\quad 13$

Figure 4. Barbara Nissman giving a master class in Berkeley, California. 16

Figure 5. Barbara Nissman at the Concertgebouw, Amsterdam. 17

Figure 6. First page of the manuscript of Ginastera’s Piano Sonata No. 3, Op. 55.

Figure 7. Cover Photo of CD Alberto Ginastera: The Complete Music for Piano \& Piano Chamber Ensemble. $\quad 27$

Figure 8. Cover Photo of Book Bartók and the Piano: A Performer's View. 31

Figure 9. Cover Photo of DVD Franz Liszt: Portrait of the Man \& his Masterwork - The Sonata in B Minor. $\quad 40$

Figure 10. Barbara Nissman performing with the West Virginia Symphony Orchestra. 44

Figure 11. Barbara Nissman and Oleg Prokofiev in London. 47

Figure 12. Cover Photo of CD Prokofiev by Nissman. 49

Figure 13. Barbara Nissman at the Prokofiev Archive dedication at Columbia University in New York City. $\quad 50$

Figure 14. Barbara Nissman performing at de Young Museum in San Francisco. 67

Figure 15. Barbara Nissman at my wedding in Charleston, South Carolina. 70 


\section{CHAPTER I}

\section{BIOGRAPHY OF BARBARA NISSMAN}

Since I was a child, music has always transported me to a special place, to a secret world, to a world of magic. And it still does, and it feeds and nurtures my soul. I can't imagine a world without music and I certainly can't imagine my world without the piano. It makes me feel better. It's good for my soul and it's always been my secret best friend. ${ }^{1}$

- Barbara Nissman

American concert pianist Barbara Nissman was born on December 31 ${ }^{\text {st }}$, 1944, in

Philadelphia, Pennsylvania. Her father Albert Nissman was an accountant, and her mother

Sophia Nissman was a full-time housewife. Although Nissman's parents were not musically

inclined, they supported the musical education of their two daughters. In an interview, Nissman

talks about her first memories of the instrument:

My first memories of music in our home was hearing my older sister practicing the piano - I remember her learning the C\# minor Prelude of Rachmaninoff - that is probably when I first fell in love with the sound of the instrument and then begged my mother to let me have piano lessons, too. ${ }^{2}$

Barbara Nissman enjoyed a rich musical environment during her school years as she remembers:

I attended the Philadelphia public schools; this was the "golden age" of music education and there was lots of exposure to music: free music lessons offered every Saturday by Philadelphia Orchestra musicians; student tickets to Philadelphia Orchestra concerts and exceptional music instruction within the orchestral and choir programs. An elective was also offered to study theory and harmony as part of my high school curriculum; as a result, I was able to pass into advanced level theory when I enrolled at University. ${ }^{3}$

\footnotetext{
${ }^{1}$ Barbara Nissman, Why I Play Steinway, Steinway \& Sons, accessed October 23, 2018, https://www.youtube.com/watch?v=yq2H6yvBi0Q. Words transcribed from video by author.

${ }^{2}$ Interview with Barbara Nissman. Answer sent by email on 10/14/18.

3 Ibid.
} 
Nissman began piano lessons with a local piano teacher when she was five years old. Her first few years of piano lessons were not very successful, but her love for the instrument made her persevere. After some years, she found her own way and decided to follow her passion for the piano as a profession for life. Nissman recalls this unusual beginning:

I was definitely not a "music prodigy.” In fact, my first piano teacher even told my mother that she was wasting her money and that her little girl was never going to be a pianist, but my mother understood how much I loved the piano and we continued. Perhaps the problem with my first piano teacher was that he taught every student the exact same way. He used a "rote" system to teach a child how to read music: "repeat after me- first line e, second line g, etc.” At my young age this approach did not work as I had no real understanding of what he was saying. I believe that I learned when I was ready to learn. The light-bulb went on later for me than for most children; I definitely was a "late-bloomer." By the age of 11 , I was reading and playing the piano and also performing locally, and by the age of $15 \mathrm{knew}$ that I wanted to be a pianist and spend my life with music. When I was in high school, I remember seeing Van Cliburn on the stage of the Academy of Music in Philadelphia and saying to myself: That is what I want to do with my life! $!^{4}$

While in high school, Barbara Nissman took piano lessons once a month with Frances

Mann, then the director of the preparatory division at the Juilliard School in New York City.

During these years, Nissman was also in search for schools to attend after high school. She

explains her studies with Ms. Mann and her search for undergraduate schools:

She gave me the basic repertoire of the piano: Sonatas by Mozart and Beethoven, Bach Preludes and Fugues, Italian Concerto, Chopin Scherzo No. 2, Mendelssohn Rondo Capriccioso etc. and of course, scales and arpeggios were a requirement. Ms. Mann wanted me to enroll at Juilliard for my college studies, but that was not an option as my parents were strongly opposed to a conservatory education. My father had attended the University of Pennsylvania and wanted me to enroll there. I remember a meeting there with the composer George Rochberg who advised me that

\footnotetext{
${ }^{4}$ Interview with Barbara Nissman. Answer sent by email on 10/14/18.
} 
since I was a performer and not a musicologist, this school was definitely not for me. ${ }^{5}$

Barbara Nissman started her undergraduate studies in music at the University of

Michigan in 1962. She completed her Bachelor's degree on a four-year full-tuition scholarship.

She also received additional scholarships during her undergraduate studies including the

Alumnae Memorial Scholarship, the Brinkman Memorial Award and the Moore Scholarship. ${ }^{6}$

Nissman describes her choice of school and her experience studying at the University of

Michigan:

I applied to the University of Michigan and was offered a full tuition scholarship (including room \& board). This became the best option even though my parents were reluctant to send their youngest daughter away from home. The University turned out to be the perfect place for me to grow and develop not only as a musician, but also as a human being. I was able to obtain a liberal arts education while at the same time concentrating on my musical studies. $^{7}$

In 1966, Barbara Nissman received the highest music award given by the University, the Stanley Medal, awarded to the most outstanding student in the School of Music. ${ }^{8}$ Also in 1966, she received a three-year fellowship under the National Defense Education Act, Title IV to continue her master and doctoral studies at the University of Michigan. She received her Master of Music degree in December of 1966 and her Doctor of Musical Arts degree in August of 1969. ${ }^{9}$ After graduation, Nissman received a post-doctoral grant from the University of Michigan Power Foundation sponsoring an international concert tour. This three-year award allowed her to

\footnotetext{
${ }^{5}$ Interview with Barbara Nissman. Answer sent by email on 10/14/18.

${ }^{6}$ Barbara Nissman, Curriculum vitae.

${ }^{7}$ Interview with Barbara Nissman. Answer sent by email on 10/14/18.

${ }^{8}$ Barbara Nissman, Curriculum vitae.

${ }^{9}$ Ibid.
} 
launch her international career. Nissman speaks about her years at the University of Michigan with great appreciation:

I spent seven years at Michigan and during that time period received my bachelor's, master's and doctoral degrees. The University was extremely generous and awarded me a grant to obtain my masters and doctorate. I was delighted because it meant I could concentrate more intensely on the piano before embarking on a solo career. The University also awarded me a post-doctoral grant from the Power Foundation to begin my international career. $^{10}$

During the seven years at the University of Michigan, Barbara Nissman studied piano with legendary concert pianist György Sándor. Nissman recalls how she began studying with this renowned artist:

When I arrived at the University of Michigan I learned that György Sándor was on the faculty but was told that he only accepted doctoral students. I applied to study with him, and he accepted me as a freshman. At that time he was touring quite a bit, but I would receive lessons whenever he returned - sometimes several lessons in one week, and since I learned quickly I always had lots of repertoire to play for him. ${ }^{11}$

Hungarian pianist György Sándor (1912-2005) was an acclaimed international concert artist. He studied at the Liszt Academy in Budapest with Béla Bartók and Zoltán Kodály. His international career includes performances in the most important halls in Europe and the United States, including Carnegie Hall, the Paris Conservatory, the Jerusalem Music Center, and the Mozarteum in Salzburg, among others. Due to political tensions in Europe, Sándor immigrated to the United States in 1939, and in 1943 he became an American citizen. Sándor is widely recognized for his recordings of the complete solo piano works of Bartók, Kodály and Prokofiev. In 1946, Sándor premiered Bartók’s Piano Concerto No. 3 in E Major (1945) with the

\footnotetext{
${ }^{10}$ Interview with Barbara Nissman. Answer sent by email on 10/14/18.

${ }^{11}$ Ibid.
} 
Philadelphia Orchestra conducted by Eugene Ormandy in Philadelphia and in Carnegie Hall in New York. György Sándor was recognized with the Grand Prix du Disque in 1965 for his complete recordings of Béla Bartók. Sándor is also the author of the book On Piano Playing: Motion, Sound and Expression. This book, published by Schirmer Books in 1981, is an in-depth exploration of piano technique and musical problems pianists often encounter. The following year, 1982, Sándor received Hungary’s highest award for artistic achievement. György Sándor was also a devoted teacher. He taught piano at Southern Methodist University (1956-1961), the University of Michigan (1961-1981) and the Juilliard School (beginning in 1982). Among his most famous students are Barbara Nissman, Ian Pace, Malcolm Bilson and Hélène Grimaud. In 1996, New York University awarded Sándor with an honorary doctorate. György Sándor died of heart failure in New York in 2005. ${ }^{12}$

For pianist Barbara Nissman, Sándor was the ideal teacher who helped her develop a strong piano technique and a deep understanding of structure in piano music. He provided Nissman with the necessary tools to become a concert artist:

I came to Sandor as a talented young pianist - however I had no idea about piano technique. I thought naively that if you practiced enough and with sufficient repetition, all problems would be solved... He helped me to coordinate my entire body into my piano playing, by also making use of the wrist, the arms, the back muscles and taking full advantage of the force of gravity to enhance sound production and produce a warm rich sound... The emphasis was always on the larger form and structure, the longer line, the bigger picture, the character of the work, choosing the tempo giusto, with everything shaped within the parameters of good taste and musical intelligence... Sandor provided me with the

\footnotetext{
${ }^{12}$ Biography based on three sources: Joseph Stevenson, György Sándor: Biography, https://www.allmusic.com/artist/gy\%C3\%B6rgy-s\%C3\%A1ndor-mn0001646651/biography; Ben Sisario, “Gyorgy Sandor, Pianist Who Trained Under Bartok, Is Dead at 93,” in The New York Times, December 14, 2005, https://www.nytimes.com/2005/12/14/arts/music/gyorgy-sandor-pianist-who-trained-under-bartok-is-dead-at93.html; and "György Sándor," in Wikipedia, https://en.wikipedia.org/wiki/Gy\%C3\%B6rgy_S\%C3\%A1ndor. All websites accessed October 23, 2018.
} 
strong foundation necessary to become a romantic bravura pianist and tackle the large repertoire. ${ }^{13}$

The year of 1970 was a significant year in the performing career of Barbara Nissman.

During this year, she met Argentinian composer Alberto Ginastera at the University of Michigan Contemporary Musical Festival. At this festival, Nissman performed Ginastera’s First Piano Concerto (1961) with the University of Michigan Symphony Orchestra. This first concert marked the beginning of a close friendship between Nissman and Ginastera.

Barbara Nissman’s international career was personally launched by Hungarian-born conductor Eugene Ormandy. ${ }^{14}$ During Nissman’s doctoral studies at the University of Michigan, she had played for Maestro Ormandy who soon after invited her to perform with him. It was Ormandy who arranged Nissman’s first European Tour in 1970, performing in all the major European capitals. ${ }^{15}$ After this successful tour, Nissman was reengaged to perform as soloist with orchestras and in recitals in annual European tours (1971-1991) including concerts in Germany, Holland, Belgium, England, Spain, Switzerland, Austria, and Scandinavia. ${ }^{16}$ On these tours she performed as soloist with major European orchestras including the London Philharmonic, the Rotterdam Philharmonic, the Royal Philharmonic, the Munich Philharmonic, l’Orchestre de la Suisse Romande, the Netherlands Chamber Orchestra, the BBC Symphony, and the Bavarian Radio Orchestra, among others.

Barbara Nissman made her American professional debut with the Philadelphia Orchestra in 1972 playing Rachmaninoff's Rhapsody on a Theme of Paganini under the baton of Eugene Ormandy. During the next several years, she also performed in the United State as a soloist with

\footnotetext{
${ }^{13}$ Interview with Barbara Nissman. Answer sent by email on 10/14/18.

${ }^{14}$ Barbara Nissman, “Biography,” in Barbara Nissman, accessed October 23, 2018, https://www.barbaranissman.com/page2.

${ }^{15}$ Barbara Nissman, Curriculum vitae.

${ }^{16}$ Ibid.
} 
the New York Philharmonic, the Chicago Symphony Orchestra, the St. Louis Symphony, the Cleveland Orchestra, the Minnesota Orchestra, the Milwaukee Orchestra, the National Symphony Orchestra, the Boston Pops, and the Pittsburgh Symphony Orchestra, among others. ${ }^{17}$ For several of these concerts, she had the opportunity to work closely with legendary conductors such as Riccardo Muti, Stanislaw Skrowaczewski and Leonard Slatkin. Additionally, Nissman gave concert tours in Russia (1984, 1998, 2002); New Zealand (2001); the Far East (1980, 1986); South America (1974, 1999, 2000, 2005); and Eastern Europe (1970, 1979). ${ }^{18}$

Barbara Nissman has also performed in numerous outreach recitals, concerts and lectures. She firmly believes that classical music should be accessible to all people and constantly works towards reaching a variety of audiences. She has given informal concerts in factories, community centers, schools, prisons, Native American reservations, hospitals, shopping centers, and construction sites. ${ }^{19}$ From 1977 to 1980 , Nissman worked as Artist-in-Residence for the John Deere Corporation. This was a position that included recitals and lectures in John Deere's plants and factories in the United States, Europe and Mexico. Nissman remembers her unusual first appearance:

Hired for eight weeks spread out over the year, I was asked to develop a lunchtime series for the workers. The Steinway was wheeled into the lunchroom; the machines were turned off, and for 40 minutes, the men, while eating their brown bag lunches, listened to me talk about my good "friends", Liszt, Chopin, Prokofiev, Rachmaninoff. As I walked into my very first concert, one of the guys yelled out to me - "Hey Blondie, how about a little Clair-de-Loonie!!” Luckily, I had that in my fingers that day. The ice was broken, and I played and chatted and shared with them the music that I was so passionate about. Then I invited all of them to come to my evening concert - that was also part of my deal with John Deere - to develop a lecture series for the general public -

\footnotetext{
${ }^{17}$ Barbara Nissman, Curriculum vitae.

${ }^{18}$ Ibid.

${ }^{19}$ Ibid.
} 
and I was lecturing that evening on the Liszt Sonata. And the good news is that so many of these men dressed up to come to my lecture with their families that evening. ${ }^{20}$

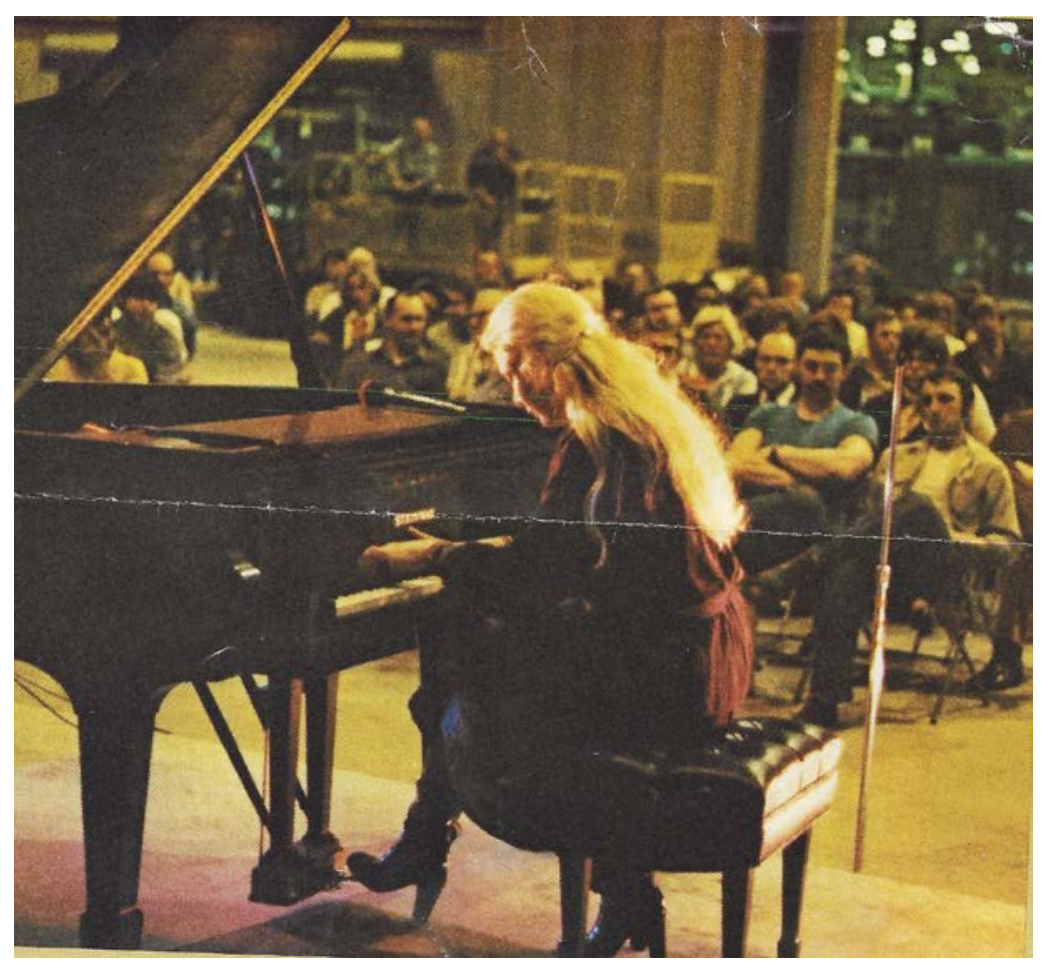

Figure 1. Barbara Nissman performing a recital at a John Deere factory.

In 1981, Barbara Nissman received the Alumnae Athena Award from the University of Michigan "in recognition of the professional distinction and humanitarianism which have characterized her career."${ }^{21}$ And in 1996, Nissman also received the Citation of Merit Award given by the Alumnae Association of the University of Michigan for her exceptional contribution to the arts. ${ }^{22}$

\footnotetext{
${ }^{20}$ Barbara Nissman, "Music for Every Man: March 10, 2018” in Piano Connections with Barbara (blog). Three Oranges Recordings, accessed October 23, 2018, https://threeorangesrecordings.com/blog/blog/music-foreveryman-march-10-2018.

${ }^{21}$ Barbara Nissman, Curriculum vitae.

${ }^{22}$ Ibid.
} 
Early in her career, Barbara Nissman created an innovative music series called "Barbara \& Friends." These were lecture-recitals in which she introduced the work of great composers to the general public. These programs became a weekly television series recorded and aired in the United States through Public Television Stations in Phoenix, Arizona (1974-1975) and WQADTV in Moline, Illinois (1977-1980). From 1978 to 1980, Nissman appeared on the popular British television program "Pebble Mill at One” produced by BBC television. During these television shows, she presented her program "Barbara \& Friends" every week in a series of three eight-week groups. ${ }^{23}$ In 1978, the BBC made a documentary film about Barbara Nissman which highlighted her artistic and educational work. This documentary was aired on BBC Television.

In 1976, Alberto Ginastera invited Nissman to perform his Piano Concerto No. 1 for his $60^{\text {th }}$ birthday celebration in Geneva. Nissman played on this occasion with l'Orchestre de la Suisse Romande conducted by Jean-Marie Auberson. A few years later, in 1982, Ginastera wrote and dedicated his Piano Sonata No. 3, Op. 54 (Ginastera’s last composition) to Barbara Nissman. She premiered this composition on November $17^{\text {th }}, 1982$, during her New York debut recital at Alice Tully Hall in Lincoln Center. ${ }^{24}$ Also in 1982, Nissman performed in the first Gracht Concert held in Amsterdam. These concerts, performed every year on the canal, have become a popular summer tradition in Holland. ${ }^{25}$

\footnotetext{
${ }^{23}$ Barbara Nissman, Curriculum vitae.

${ }^{24}$ Ibid.

${ }^{25}$ Ibid.
} 


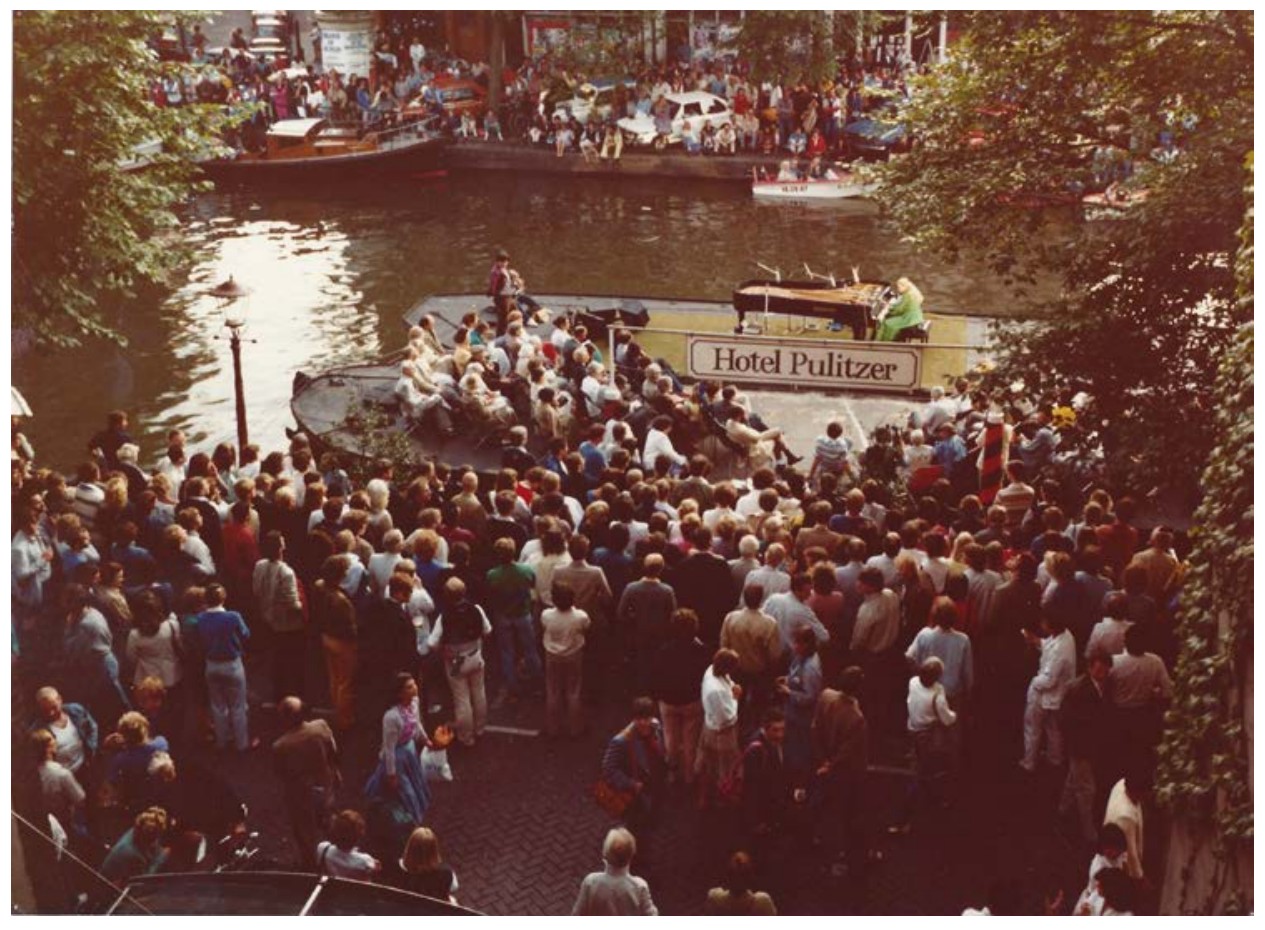

Figure 2. Barbara Nissman performing in the first Gracht Concert in Amsterdam in 1982.

In 1983, Nissman performed in a memorial concert for Alberto Ginastera at the Cathedral Church of St. John the Divine in New York City. There she met poet Daniel Haberman who was serving as a poet-in-residence at the Cathedral. They married in 1987 and in 1989, they moved to a farm they bought together in Greenbrier County, West Virginia. ${ }^{26}$

Barbara Nissman became a Steinway Artist in 1972 and since then, she has continued to represent this world-renowned company with concerts and recitals around the world. As a distinguished Steinway artist, she was selected to participate in the commemorative concert "In Celebration of the Piano: An All-Star Tribute to the Steinway” on June 2nd, 1988 in Carnegie Hall. This event - hosted by famous concert pianist Van Cliburn - celebrated Steinway’s $135^{\text {th }}$ Anniversary. On this concert, Nissman shared the stage with some of the finest international

\footnotetext{
${ }^{26}$ Interview with Barbara Nissman. Answer sent by email on 10/14/18.
} 
concert pianists including Alexis Weissenberg, Shura Cherkassky, Jean-Yves Thibaudet, Stephen Hough, and Ruth Laredo, among other legendary pianists. ${ }^{27}$

1989 was another crucial year in the performing career of Barbara Nissman. During this year, she made history by becoming the first pianist to perform the complete piano sonatas of Sergei Prokofiev in a series of three-recitals. These concerts were held in Lincoln Center, New York and Wigmore Hall, London. ${ }^{28}$ She also became the first pianist to record the complete piano sonatas by Prokofiev on compact disc. In 1991 and in commemoration of the composer's $100^{\text {th }}$ birthday, Nissman performed the complete sonatas throughout Europe and the United States; and in 2003 in commemoration of the $50^{\text {th }}$ anniversary of the death of Sergei Prokofiev, Nissman performed all five piano concertos again throughout Europe and the United States. ${ }^{29}$ In addition, Nissman has given recitals, master classes, and lectures on the piano music of Sergei Prokofiev in Russia, the United Kingdom, Holland, and the United States including the Moscow Conservatory, St. Petersburg Conservatory, the University of London, and Columbia University in New York.

In 1991, Barbara Nissman’s life was significantly impacted by the tragic loss of her husband Daniel Haberman, who had been diagnosed two-years previously with a terminal illness. After his death, Nissman took a time away from concert life. ${ }^{30}$ Fortunately, after a few years and with the help of friends, she began performing again.

In 1996, Nissman was selected to perform at the Kennedy Center $25^{\text {th }}$ Anniversary Gala Concert The 100 Flying Fingers which was broadcasted by the PBS Television. Music

\footnotetext{
${ }^{27}$ Michael Bernhaut, Van Cliburn, et al., In celebration of the piano: An all-star tribute to the Steinway, DVD, New York: Video Artists International, 2005.

${ }^{28}$ Barbara Nissman, Curriculum vitae.

${ }^{29}$ Barbara Nissman, “Biography: Prokofiev” in Barbara Nissman, accessed October 23, 2018, https://www.barbaranissman.com/page2.

${ }^{30}$ Interview with Barbara Nissman. Answer sent by email on 10/14/18.
} 
compositions were arranged for 10 pianos for this event. Nissman performed together with Leonard Slatkin, Peter Nero, and Joseph Kalichstein, among others. ${ }^{31}$

Nissman was granted entry into the first class of the Steinway Hall of Legends in 2003. Twenty-four pianists (both living and deceased) were chosen from the complete list of Steinway Artists. They were honored and featured in the Steinway \& Sons' $150^{\text {th }}$ Anniversary Commemorative Publication. Some of the world-class concert pianists also highlighted in the article are Murray Perahia, Van Cliburn, Rudolf Serkin, Alfred Brendel, Mauricio Pollini, Mitsuko Uchida, Martha Argerich, Daniel Barenboim, and Evgeny Kissin. ${ }^{32}$

Barbara Nissman has also performed in various fundraiser events for the community, healthcare and environmental preservation. Nissman has participated in the benefit concert series A Concerted Effort for the Robert James Frascino AIDS Foundation since 2002, raising money for service organizations around the world. On October $4^{\text {th }}, 2007$, Nissman performed in the gala fundraising event for the Walden Woods Project held in the Allen Room of Jazz at Lincoln Center in New York City. On this occasion, she shared the stage with Don Henley and Billy Joel in an effort to raise money to support global environmental and social reform. ${ }^{33}$

\footnotetext{
${ }^{31}$ Barbara Nissman, Curriculum vitae.

${ }^{32}$ Ibid.

${ }^{33}$ Barbara Nissman, "Biography,” in Barbara Nissman, accessed October 23, 2018, https://www.barbaranissman.com/page2.
} 


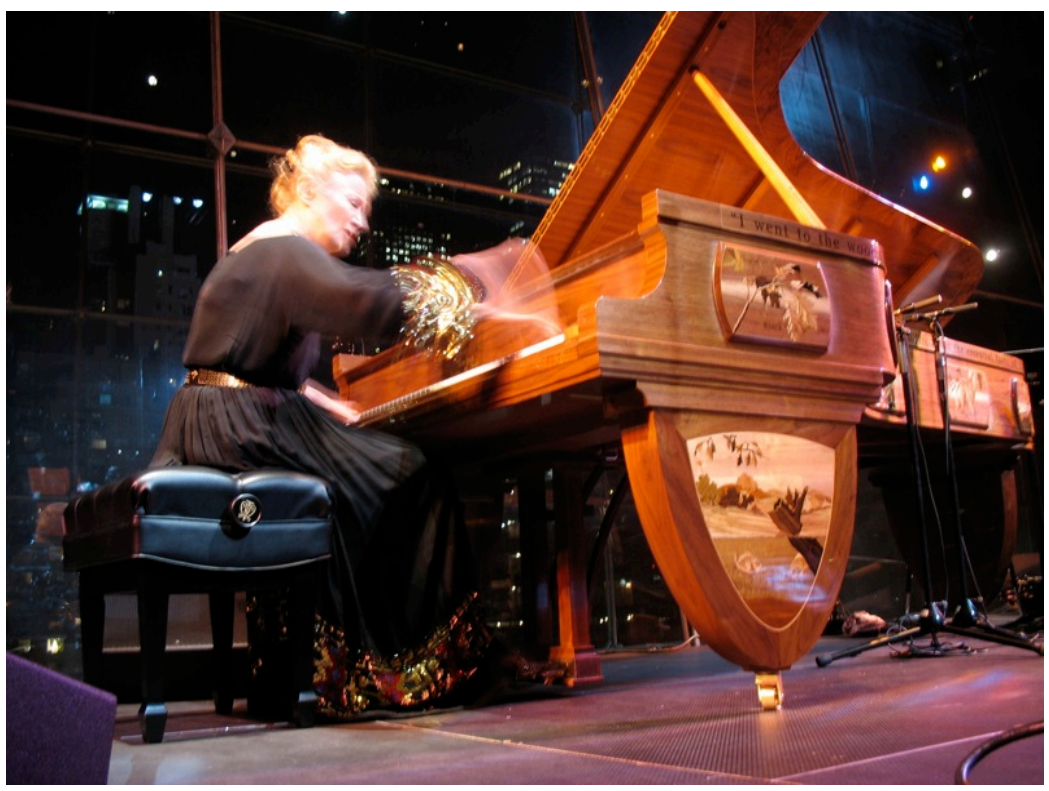

Figure 3. Barbara Nissman performing at a fundraising concert for the Walden Woods Project at Lincoln Center in New York City on October $4^{\text {th }}, 2007$.

In 2011, Barbara Nissman performed and recorded Alberto Ginastera’s complete piano concertos with the University of Michigan Symphony Orchestra conducted by Kenneth Kiesler. In this concert, she premiered Ginastera's Concerto Argentino (1935) and the original version of the Piano Concerto No. 2, Op. 39 (1972). This recording is the first album of the complete set of piano concertos written by Alberto Ginastera.

Nissman is also highly praised for her numerous writings about the piano music of the great composers from the nineteenth and twentieth centuries. As an example, her book Bartók and the Piano: A Performer's View (Scarecrow Press, 2002) offers an extensive study of this composer's piano music. In addition, Nissman’s articles have been published in prestigious music magazines such as Piano Today, Musical Opinion, Keyboard Classics, International Piano (UK), Piano (UK), and Musical Times (UK). Among her most significant publications are “Sergei Prokofiev: A Man Misunderstood” included in the book The Pianist's Craft (Scarecrow 
Press, 2012) and “Remembering Alberto Ginastera” included in the book The Pianist's Craft 2 (Rowman \& Littlefield, 2015). Nissman has also participated in the symposiums “Prokofiev’s Pianism” (2013) and “Understanding Bartók” (2014) for the prestigious British magazine International Piano (UK). Other pianists included in these notable symposiums are Vladimir Ashkenazy, Peter Donohoe, Jenö Jandó, Boris Berman, and Zoltán Kocsis among others.

In 2014, Barbara Nissman launched her own record label Three Oranges Recordings. To celebrate this important accomplishment, she gave a recital on June $19^{\text {th }}$, 2014 at Steinway Hall in New York City. Nissman’s discography includes the piano music of Beethoven, Liszt, Brahms, Chopin, Schumann, and Rachmaninoff, among other major composers. In addition, her recordings of the piano music of Ginastera, Prokofiev, and Bartók have received exceptional recognition, being considered as “definitive.”34 Since 2014, over 25 of her recordings have been published by Nissman's Three Oranges Recordings label with the goal of reaching more diverse audiences. More recently, in 2017, Nissman created the Three Oranges Foundation with the similar purpose of making music available to more people. Nissman further explains:

We have established the Three Oranges Foundation to continue our educational work through concerts, lectures, recordings, masterclasses, symphonic appearances, and a new educational DVD series. Our purpose is to take classical music to the people and to make a difference in people's lives - touching souls - giving them a sense of hope - inspiring them to reach for the impossible! ${ }^{35}$

In 2016, Barbara Nissman released the first DVD of her educational series. This twoDVD set entitled Franz Liszt: A Portrait of the Man \& his Masterwork - The Sonata in B minor features a lecture on the life of Franz Liszt and a master class and performance of the great

\footnotetext{
${ }^{34}$ Barbara Nissman, "Biography: Prokofiev,” in Barbara Nissman, accessed October 23, 2018, https://www.barbaranissman.com/page2.

${ }^{35}$ Barbara Nissman, "Music for Every Man: March 10, 2018," in Piano Connections with Barbara (blog). Three Oranges Recordings, accessed October 23, 2018, https://threeorangesrecordings.com/blog/blog/music-foreveryman-march-10-2018.
} 
Sonata in B minor. Nissman is currently working on her second DVD Alberto Ginastera: A Man of Latin America scheduled to be released in 2019.

Nissman has led a very active performing career during the last few years. Her most important performances include playing at the opening ceremony of the Prokofiev Archive at Columbia University in New York City (2015); her lecture recital commemorating the $100^{\text {th }}$ Anniversary of the birth of Alberto Ginastera at the Embassy of Argentina in Washington, DC (2016); her performance as the featured artist in the International Prokofiev Symposium at the Louisiana State University (2016); and her performance of Liszt's Totentanz with the West

Virginia Symphony Orchestra conducted by Lawrence Loh (2018).

Barbara Nissman is not only praised as one of the finest pianists of our times, but she is also recognized as a passionate guest teacher and clinician. She explains:

First of all, I enjoy giving master classes. The exchange of ideas, the give and take that occurs between students as well as the observing public, and the challenge of trying to bring out the best that each individual can offer is exciting! To hear an interpretation develop, ripen, and focus becomes a magical experience for both the student and the teacher. A fresh outlook, another point of view, and a new way of solving problems provide learning tools for everyone, myself included. ${ }^{36}$

\footnotetext{
${ }^{36}$ Barbara Nissman, “Master Classes: In Her Own Words,” in Barbara Nissman, accessed October 23, 2018, https://www.barbaranissman.com/in-her-own-words.
} 


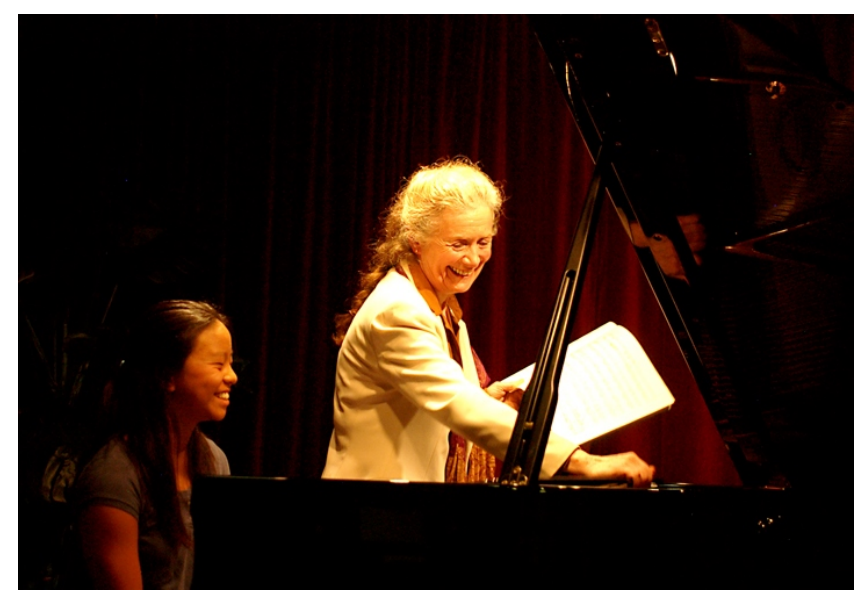

Figure 4. Barbara Nissman giving a master class in Berkeley, California in 2009.

Nissman is frequently invited to present master classes, recitals, and lectures in universities and colleges around the world. She has given master classes in some of the most renowned schools including the Royal Academy of Music in London, the Canterbury University in New Zealand, the University of Groningen in the Netherlands, the Singapore Conservatory of Music, the Moscow Conservatory, the St. Petersburg Conservatory, and the Federal University in Salvador, Brazil. Schools in the United States include the Juilliard School, Northwestern University, Oberlin Conservatory of Music, Boston Conservatory of Music, University of Michigan, Indiana University, University of California, DePauw University, Duquesne University, and West Virginia University. ${ }^{37}$ These master classes and lectures have deepened piano students' understanding of the music they perform, causing them to advance their own artistic journeys. Nissman explains:

The purpose of my visit as a guest artist/teacher is to focus and sharpen the ears, enhance the insight, and, above all, to give a young student the necessary tools and freedom to clarify their own pathway to the next level. ${ }^{38}$

\footnotetext{
${ }^{37}$ Barbara Nissman, Curriculum vitae.

${ }^{38}$ Barbara Nissman, "Master Classes: In Her Own Words," in Barbara Nissman, accessed October 23, 2018, https://www.barbaranissman.com/in-her-own-words.
} 


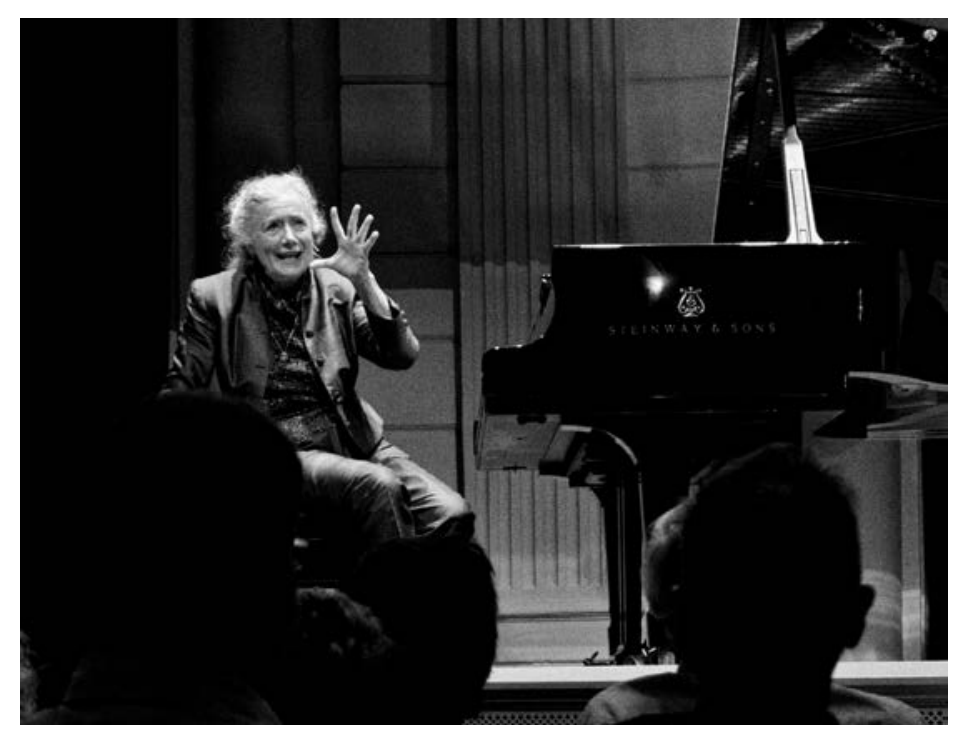

Figure 5. Barbara Nissman in a lecture recital at the Concertgebouw, Amsterdam in 2017.

In 2008, Barbara Nissman received the illustrious "Governor's Arts Award” from the State of West Virginia. This award was given in recognition of her exceptional contribution to music and the arts. And in March 2016, Nissman was honored with the "Excellence in Support of the Arts” award from the West Virginia Division of Culture and History. This award was given in recognition of her extraordinary contribution to culture in West Virginia. ${ }^{39}$ Currently, Barbara Nissman lives in Lewisburg, in the Allegheny Mountains of West Virginia. She enjoys the countryside and living in her farmhouse:

I feel blessed to live in the country. It's a wonderful place for me to work and just to be. And after breakfast, I walk across the backyard to my studio. And every day is different because I have no idea where my nose will lead me. ${ }^{40}$

\footnotetext{
39 "Division News" in West Virginia Division of Arts, Culture and History, accessed October 23, 2018, http://www.wvculture.org/news.aspx?Id=2770\&Agency=Division.

${ }^{40}$ Barbara Nissman, Why I Play Steinway, Steinway \& Sons, accessed October 23, 2018, https://www.youtube.com/watch?v=yq2H6yvBi0Q. Words transcribed from video by author.
} 


\section{CHAPTER II}

\section{BARBARA NISSMAN ON ALBERTO GINASTERA'S PIANO MUSIC}

How wonderful to rediscover a composer who can make us feel, who puts us back in touch with our passions and reaches deep into our soul. ${ }^{41}$

- Barbara Nissman

Alberto Evaristo Ginastera (1916-1983) is recognized as one of the most influential composers of Latin America and one of the leading composers of the twentieth century. Born in Buenos Aires, Argentina, Ginastera studied music at the Conservatorio Williams de Buenos Aires (1928-1935) and at the Conservatorio Nacional de Música de Buenos Aires (1936-1938). Among his most influential music teachers in Argentina were José André, Athos Palma, Cayetano Argenziani, and José Gil. He was also greatly influenced and inspired by American composer Aaron Copland with whom he studied composition and kept a close relationship through the years. Ginastera later received three honorary doctorates from Yale University, Temple University, and the Universidad Nacional de La Plata. During his life, Ginastera was awarded several important grants, prizes, and awards in South America, Europe, and the United States including the Guggenheim Memorial Foundation Grant, the Deutscher Akademischer Austausch Dienst Grant, the Ordre des Arts et es Lettres Award given by the French government, the Grand Prize from the Argentine Fondo Nacional de las Artes, and the UNESCO International Music Prize in honor of his lifetime creative achievement. ${ }^{42}$

\footnotetext{
${ }^{41}$ Barbara Nissman, "Remembering Alberto Ginastera," in The Pianist's Craft 2: Mastering the Works of More Great Composers, ed. Richard P. Anderson, (Lanham, Md.: Rowman \& Littlefield, 2015), 134.

${ }^{42}$ Deborah Schwartz-Kates, Alberto Ginastera: A Research and Information Guide, Routledge Music Bibliographies, (New York: Routledge, 2010), xviii-xxvi.
} 
Alberto Ginastera had a very successful career as a composer having several of his works premiered by world-renowned artists such as Ruggiero Ricci, Eugene Ormandy, Leonard Bernstein, Mstislav Rostropovich, Aurora Nátola-Ginastera, the Juilliard String Quartet, the Emerson, Lake \& Palmer rock group, and Barbara Nissman. Ginastera’s catalogue of compositions is vast and covers many different genres of music including works for piano; organ; harp; guitar; violin; and cello; as well as chamber music; vocal/choral music; orchestral music; ballets; film scores; and incidental music. ${ }^{43}$ Among his most popular compositions for piano are Danzas Argentinas Op. 2 (1937); Sonata No. 1, Op. 22 (1952); Doce Preludios Americanos Op. 12 (1944); and the Piano Concerto No. 1 (1961). During the last years of his life, Alberto Ginastera suffered from a terminal cancer and died in Geneva, Switzerland in 1983.

Pianist Barbara Nissman is considered to be a leading expert and one of the finest interpreters of Ginastera's music for piano. She had the privilege of working closely with the composer, with whom she shared a wonderful friendship for many years. Ginastera had a great admiration for Nissman’s artistry, describing her as “a magnificent interpreter of my music - one of the best pianists in the world." ${ }^{44}$ Barbara Nissman has done extensive work on Ginastera’s piano music including numerous recordings, articles, a book chapter, score editions, concerts, lectures, and master classes. Nissman's major contribution to the literature and discography of the piano music of Alberto Ginastera includes the reintroduction of the withdrawn Concierto Argentino, the restoration of the original version of the Piano Concerto No. 2, and her recordings of the complete music for piano, piano chamber music, and piano concertos written by this extraordinary composer. In 2019, she is scheduled to release a DVD entitled Alberto Ginastera:

\footnotetext{
${ }^{43}$ Deborah Schwartz-Kates, Alberto Ginastera: A Research and Information Guide, Routledge Music Bibliographies, (New York: Routledge, 2010), 40-94.

${ }^{44}$ Barbara Nissman, "Recordings: Ginastera,” in Barbara Nissman, accessed October 20, 2018, https://www.barbaranissman.com/ginastera.
} 
A Man of Latin America which will offer an exploration of the life and music of the composer, including fascinating interviews and an inspiring master class on various piano compositions. Featured on this DVD are extraordinary interviews with Alberto Ginastera, Aurora NátolaGinastera (his wife), Georgina Ginastera (his daughter), conductor Leonard Slatkin, composer Marlos Nobre, rock musician Keith Emerson from Emerson, Lake \& Palmer, and jazz pianist Chick Corea. ${ }^{45}$

Over the years, Nissman has shown a great interest in the unique music of Alberto Ginastera. She has referred to the powerful rhythms, the beautiful South American melodies and the distinctive colors and imagery of the music:

This is music which could have been written only by a LatinAmerican. He does more than utilize folk-melodies; he creates his own brand of "imaginary folklore," definitely influenced by what Kodály and Bartók achieved with their use of Hungarian folkmaterial. The sounds of the pampas are part of his color world: the "night" sounds, the Latin dance rhythms - all contribute to Ginastera's personal musical language. ${ }^{46}$

Nissman often mentions as well the unique effect that the music of Ginastera has on the performer and the listener:

The sheer physical act of playing his piano music has a cathartic effect, providing a release of raw, earthy emotions that seem to transcend thought. The driving intensity, the excitement of his exuberant, unrestrained music burst forth to engulf the listener, communicating with a directness that so often eludes many of today's composers. ${ }^{47}$

As mentioned in the Chapter I, Barbara Nissman first met Alberto Ginastera in 1970 at the University of Michigan’s Contemporary Musical Festival. Nissman was invited to perform

\footnotetext{
${ }^{45}$ Barbara Nissman, email message to author, November 1, 2018.

${ }^{46}$ Nissman, Barbara, Aurora Natola-Ginastera, Ruben Gonzalez, and The Laurentian String Quartet, Alberto Ginastera: The Complete Music for Piano \& Piano Chamber Ensemble, CD. 2 vols, Pierian, 2001, Booklet, 2.

${ }^{47}$ Barbara Nissman, "Remembering Alberto Ginastera," in The Pianist's Craft 2: Mastering the Works of More Great Composers, ed. Richard P. Anderson, (Lanham, Md.: Rowman \& Littlefield, 2015), 134.
} 
the Piano Concerto No. 1 (1961) with the University of Michigan’s Symphony Orchestra in a

festival featuring the composer. Nissman remembers her first impressions of Ginastera:

We met at rehearsal - that was in 1970 - I remember him sitting in the empty hall, listening - he was enjoying himself. I expected him to be super-critical, but he was so very gracious. He didn’t look at all as I had imagined - he could have passed for a South American banker; certainly he didn't fit my visual image of the man who wrote such passionate, primitive music. ${ }^{48}$

After this first concert, Ginastera promised to write a Piano Concerto for Nissman. This music festival marked the beginning of a friendship that continued for many more years. ${ }^{49} \mathrm{~A}$ few years later, in 1976, Ginastera invited Barbara Nissman to perform his First Piano Concerto in a gala concert in Geneva featuring Nissman and celebrating the composer's sixtieth birthday.

Nissman performed the Piano Concerto No. 1 with the Orchestre de la Suisse Romande conducted by Jean-Marie Auberson. Nissman recalls:

After the performance, he came back-stage and said to me, "One day I will write a Concerto for Piano and Percussion for you.” Unfortunately because of his failing health, he never began work on our concerto. Instead, he dedicated his Third Piano Sonata to me and sadly, this short one-movement solo work, became his final composition. $^{50}$

The Piano Sonata No. 3, Op. 55 (1982) holds a very special place in Barbara Nissman’s repertoire. Over the years, Ginastera changed his mind a few times about the format of the piano piece he intended to write for Nissman. After the first concert in Michigan in 1970, Ginastera promised to write a Piano Concerto for her. The idea changed in 1976 for a Concerto for One Piano and Percussion (as opposed to the Bartók concerto for two pianos and percussion) and

\footnotetext{
${ }^{48}$ Nissman, Barbara, Aurora Natola-Ginastera, Ruben Gonzalez, and The Laurentian String Quartet, Alberto Ginastera: The Complete Music for Piano \& Piano Chamber Ensemble, CD. 2 vols, Pierian, 2001, Booklet, 1.

${ }^{49}$ Barbara Nissman, "Remembering Alberto Ginastera,” in The Pianist's Craft 2: Mastering the Works of More Great Composers, ed. Richard P. Anderson, (Lanham, Md.: Rowman \& Littlefield, 2015), 119.

${ }^{50}$ Nissman, Barbara, Aurora Natola-Ginastera, Ruben Gonzalez, and The Laurentian String Quartet, Alberto Ginastera: The Complete Music for Piano \& Piano Chamber Ensemble, CD. 2 vols, Pierian, 2001, Booklet, 2.
} 
later on, in 1982, he intended to add an Adagio Introduction to the already written Third

Sonata. ${ }^{51}$ Unfortunately, Ginastera died before making any additions to the work. Nissman

explains the circumstances in which the Third Sonata was composed:

The Third Piano Sonata was written from Ginastera's hospital bed in Switzerland and mailed to me in the United States, a few pages at a time. ${ }^{52}$

In another article, Nissman adds a reflection:

He wrote this sonata from his hospital bed in Geneva. Perhaps he knew that this would be his last compositions when he wrote the words, Deo gratias over its final measure. ${ }^{53}$

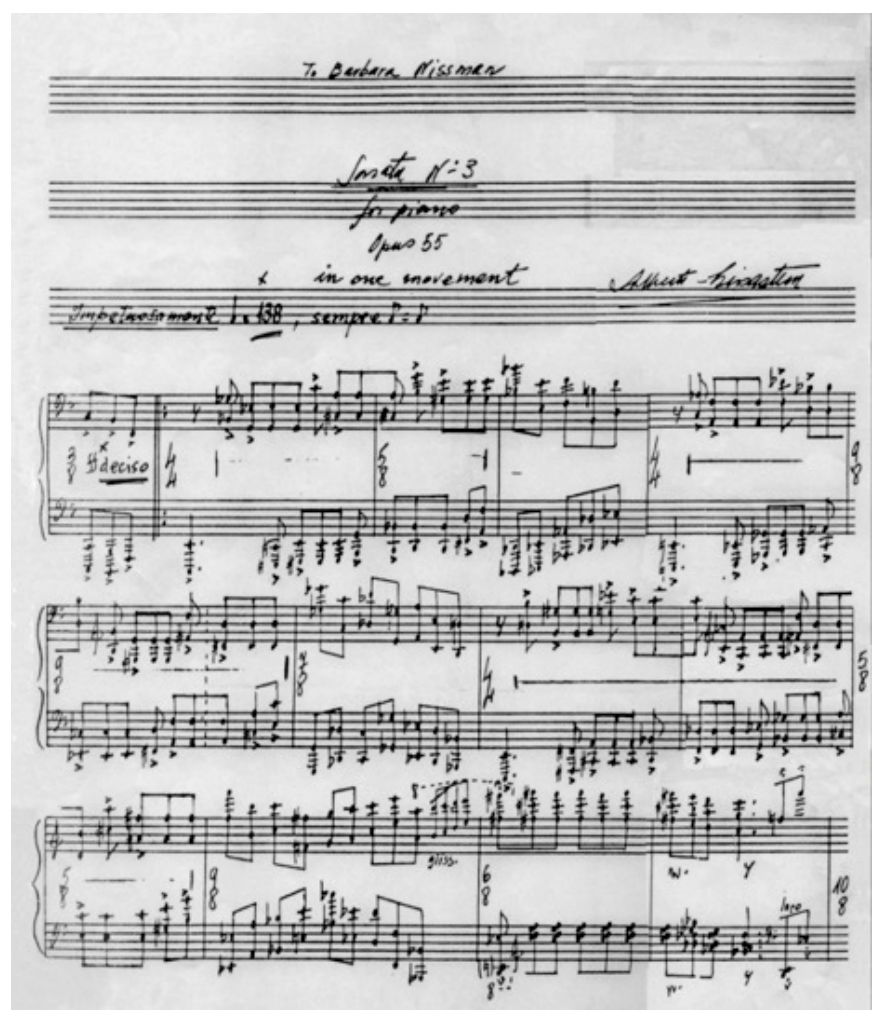

Figure 6. First page of the manuscript of Ginastera’s Piano Sonata No. 3, Op. 55 dedicated to Barbara Nissman.

\footnotetext{
${ }^{51}$ Barbara Nissman, "Remembering Alberto Ginastera," in The Pianist's Craft 2: Mastering the Works of More Great Composers, ed. Richard P. Anderson, (Lanham, Md.: Rowman \& Littlefield, 2015), 119-120.

${ }^{52}$ Ibid, 131.

${ }^{53}$ Barbara Nissman, “Deo Gratias! Remembering Alberto Ginastera (1916-1983) June 29, 2016,” in Piano Connections with Barbara (blog), Three Oranges Recordings, accessed October 20, 2018, https:/threeorangesrecordings.com/blog/blog/deo-gratias-remembering-alberto-ginastera-1916-1983-june-29-2016.
} 
The Piano Sonata No. 3 was premiered by Nissman on November $17^{\text {th }}$, 1982 in Alice Tully Hall - Lincoln Center in New York and was published by Boosey \& Hawkes in 1983.

Nissman made a major contribution to Ginastera's piano literature with the recovery of the original version of the Piano Concerto No. 2, Op. 39. This concerto was written in 1972 and was dedicated to and premiered by Austrian pianist, Hilde Somer. Unfortunately, Somer changed the score considerably, as Nissman describes:

Ginastera wrote the second movement scherzo for the right hand alone (per la mano destra). However, Ms. Somer was not pleased with this version and transcribed it herself for the left hand alone (per la mano sinistra) making significant changes to the piano writing in the process. Somer also altered the ending of the finale. ${ }^{54}$

The restored score, edited by Barbara Nissman, was published by Boosey \& Hawkes in 2016 and includes several personal and performance notes made by Nissman. One curious anecdote she includes in the score is a conversation she had with Ginastera and his wife, Aurora NátolaGinastera, about the composition of this Second Piano Concerto:

They both shared with me a funny story about a pianist who kept on calling them every day while they were on their honeymoon. The pianist was the late Hilde Somer who had commissioned the Second Piano Concerto, Op. 39, written in 1972. Ginastera was notoriously late delivering commissioned works, and she was nervous about receiving the work on time. I recall as if it were yesterday what Ginastera told me that day when he handed me a copy of the manuscript score; "I decided to make this concerto as difficult as I could to say thank you for all those phone calls."

The world premiere of the original version of the Piano Concerto No. 2, Op. 39 was performed and recorded by Barbara Nissman in December of 2011 in Hill Auditorium at the University of

\footnotetext{
${ }^{54}$ Nissman, Barbara, Kenneth Kiesler, and University of Michigan Symphony Orchestra, Nissman Plays Ginastera: The Three Piano Concertos, CD, Pierian Recording Society, 2012, Booklet, 2.

${ }^{55}$ Alberto Ginastera, Piano Concerto No. 2, Op. 39, edited by Barbara Nissman, (New York: Boosey \& Hawkes, 2016), Foreword.
} 
Michigan. It was performed by Barbara Nissman and the University of Michigan Symphony Orchestra conducted by Kenneth Kiesler.

Another important contribution made by Nissman is the reintroduction of an early composition: Ginastera's Concierto Argentino, written in 1935. It was initially premiered by Hugo Balzo in Uruguay in 1941 but was shortly after withdrawn from the catalog by the composer himself. Ginastera later expressed intentions of revising it but died before doing so. Nissman found the manuscript at the Fleisher Manuscript Collection at the Free Library of Philadelphia. She was granted exclusive permission by the late widow, Aurora Nátola-Ginastera to perform and make the first recording of the work. ${ }^{56}$

The reinstatement of the Concierto Argentino and the recovery of the original version of the Piano Concerto No. 2 brought together the piano concerto legacy of Alberto Ginastera. Barbara Nissman made an historical recording in 2011 including the three piano concertos. This recording represents the world premiere recordings of the Concierto Argentino and the Second Piano Concerto (in its original version).

Nissman had the privilege of studying Ginastera's compositional style with the composer himself. She often highlights the great importance that Ginastera put on form, structure and contrast:

What I remember most from all of our musical discussions over the years was how important form and structure were to Ginastera's craft. "A work without form is a work de-formed" was one of his favorite sayings. "Music is architecture in movement and the form must always be born with the music. It is not a different thing; it is the same thing..." He talked often about contrast within music as a vital element. "In aesthetics, as in nature, there exists the law of contrasts: day and night, the sun and

\footnotetext{
${ }^{56}$ Nissman, Barbara, Kenneth Kiesler, and University of Michigan Symphony Orchestra, Nissman Plays Ginastera: The Three Piano Concertos, CD, Pierian Recording Society, 2012, Booklet, 2-3.
} 
the moon, black and white, allegro and adagio. We must return to contrasts within music." 57

Also important in Ginastera's piano music, is the composer's awareness of the instrument and its possibilities. Nissman explains this essential characteristic:

Each time I play any one of his works, I have found that my initial instincts are still valid. His love and respect for the piano are apparent in everything he has written for the instrument; his work is always "pianistic" - it fits well under the fingers. Always in evidence is the knowledge he acquired by studying the piano music of Liszt, Bartók and Prokofiev. With this firm pianistic foundation, he proceeded down his Latin-American path. ${ }^{58}$

Even though Ginastera studied piano during his formative years, he was not a very skillful

pianist. Nissman remembers a witty answer he gave her when talking about it:

His love and respect for the piano always shines through - quite amazing considering that he was not a virtuoso pianist himself. I discovered that fact when I asked him if he played his First Sonata; he nodded his head but with a grin on his face added - "one chord per second." 59

In an interview, Barbara Nissman was asked what advice she would give to young pianists

studying the music of Alberto Ginastera, Nissman responded:

In general, Ginastera's music is quite virtuosic and a bit of a physical workout. Rhythmic repetition is an essential element and Ginastera's rhythms need to become a part of one's DNA - they need to become second nature and should never sound academic or strictly metronomic. The pulse must be maintained at all costs but the music must also breathe. Color is another important ingredient. With so much repetition going on, contrasts are extremely necessary - the more the merrier!! ${ }^{60}$

\footnotetext{
${ }^{57}$ Barbara Nissman, “Remembering Alberto Ginastera,” in The Pianist’s Craft 2: Mastering the Works of More Great Composers, ed. Richard P. Anderson, (Lanham, Md.: Rowman \& Littlefield, 2015), 120.

${ }^{58}$ Nissman, Barbara, Aurora Natola-Ginastera, Ruben Gonzalez, and The Laurentian String Quartet, Alberto Ginastera: The Complete Music for Piano \& Piano Chamber Ensemble, CD. 2 vols, Pierian, 2001, Booklet, 2.

${ }^{59}$ Barbara Nissman, "Remembering Alberto Ginastera - A Centenary Tribute,” Musical Opinion Quarterly, no. 1507 (April-June 2016): 19.

${ }^{60}$ Interview with Barbara Nissman. Answer sent by email on 10/14/18.
} 
Nissman has successfully recorded Ginastera's complete works for solo piano, chamber music with piano, and the complete piano concertos. Her recording Alberto Ginastera (published by Globe in 1988) was chosen by both Gramophone and American Record Guide as one of the best releases of $1989 .{ }^{61}$ Among her most celebrated recordings are Alberto Ginastera: The Complete Music For Piano \& Piano Chamber Ensembles in a two-volume set (issued by Newport Classics in 1991-92. Reissued by Pierian Recording Society in 2001 and by Three Oranges Recordings in 2014); and the exceptional recording entitled Nissman Plays Ginastera:

The Three Piano Concertos (issued by Pierian Recording Society in 2012). Nissman’s recordings have been highly praised in numerous reviews written by prominent critics: ${ }^{62}$

She generates a wealth of color and inexorable musical line, whether loud or soft.

Classical Net, 2014

Nissman is a player of great energy. She does not lack a sense of lyricism, however, and the sound she produces is excellent.

American Record Guide, 2001

Barbara Nissman has made Ginastera’s powerful, drivingly rhythmic and often very personal style her own.

BBC Music Magazine, 2009

\footnotetext{
${ }^{61}$ Barbara Nissman, “Recordings: Ginastera,” in Barbara Nissman, accessed October 20, 2018, https://www.barbaranissman.com/ginastera.

${ }^{62}$ Ibid.
} 


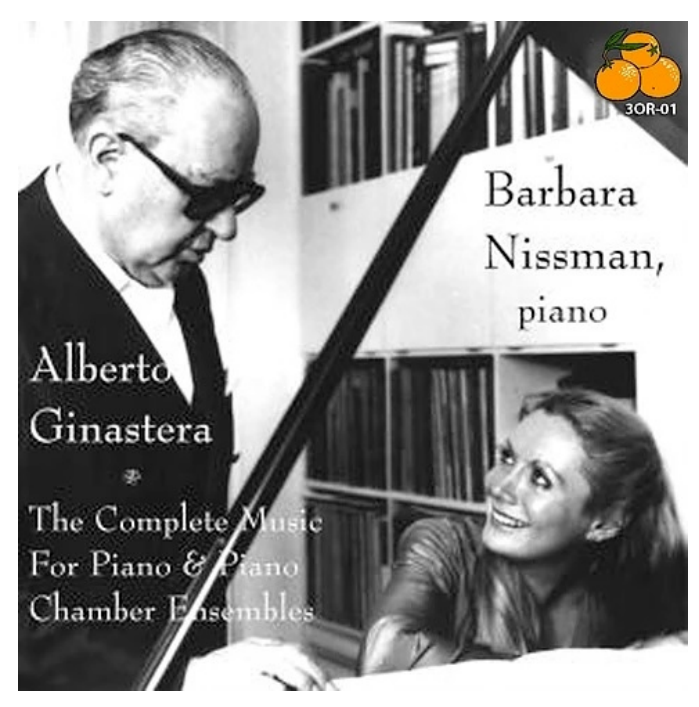

Figure 7. Cover Photo of CD Alberto Ginastera: The Complete Music for Piano \& Piano Chamber Ensemble (Three Oranges Recordings, 2014).

Nissman is also a dedicated editor and writer on Ginastera’s piano music. Her articles have been published in top music magazines around the world. Among her most significant publications are "Remembering Alberto Ginastera" (a chapter included in the book The Pianist's Craft 2: Mastering the Works of More Great Composers, edited by Richard P. Anderson), and “Remembering Alberto Ginastera - A Centenary Tribute” (published in Musical Opinion (UK) in 2006). Other articles on Ginastera's piano music have been published in Keyboard Classics, Keynote and Piano Today magazines. In addition, Nissman is considered a contributing editor of the Piano Sonata No. 2, Op. 53 (1981) and the Piano Sonata No. 3, Op.55 (1982), published in 1983 by Boosey \& Hawkes. ${ }^{63}$

In an article celebrating the $100^{\text {th }}$ anniversary of the birth of Alberto Ginastera, Nissman reminisces on the words Deo gratias that Ginastera wrote over the last measures of his final composition, the Third Piano Sonata, dedicated to Nissman. She writes:

${ }^{63}$ Barbara Nissman, Curriculum vitae. 
Deo gratias for our friendship Alberto and for all those wonderful musical discussions we were able to have. I treasure our friendship and feel blessed to have known you and your wife Aurora. Your music is so full of life and joy and passion. It inspires us to follow our hearts and pursue our dreams. What a gift you have contributed to the world and all we have to do is listen and feel its magic!! ${ }^{64}$

Barbara Nissman was privileged to enjoy a very special friendship with this extraordinary composer. She has captured the essence of Ginastera’s piano music perhaps as no other pianist has and she has devoted much of her career to sharing Ginastera's art with the world.

\footnotetext{
${ }^{64}$ Barbara Nissman, “Deo Gratias! Remembering Alberto Ginastera (1916-1983) June 29, 2016,” in Piano Connections with Barbara (blog). Three Oranges Recordings, accessed October 20, 2018, https://threeorangesrecordings.com/blog/blog/deo-gratias-remembering-alberto-ginastera-1916-1983-june-29-2016.
} 


\section{CHAPTER III}

\section{BARBARA NISSMAN ON BÉLA BARTÓK'S PIANO MUSIC}

Bartók makes pianists learn another language-his language-and demands that they speak it as if it were their mother tongue. ${ }^{65}$

- Barbara Nissman

Hungarian composer Béla Bartók (1881-1945) is well-known for his exhaustive research on Hungarian folk music and for incorporating the melodies and sounds of the countryside into his own compositions. He is considered to be one of the most influential composers of the twentieth century and one of the forefathers of the field of ethnomusicology. Bartók started his musical studies at a very early age. He first studied piano with his mother, Paula Bartók, and later with László Erkel. ${ }^{66}$ From 1899-1903, he was a student at the Budapest Academy of Music studying piano with István Thomán and composition with Hans Koessler. ${ }^{67}$ After his formal studies, Béla Bartók made numerous expeditions to the countryside of Hungary, Slovakia and Romania recording peasant's tunes, the sounds of traditional instruments and the sounds of nature. These folk tunes and sounds were later integrated in Bartók’s compositional style. Béla Bartók also dedicated a great part of his life to expanding the field of piano pedagogy. In addition to his thirty years teaching piano at the Budapest Academy for Music, he composed and transcribed a large number of piano pieces for pedagogical purposes. ${ }^{68}$ In 1940 , Bartók immigrated to the United States due to the growing political tension in Hungary and the rest of

\footnotetext{
${ }^{65}$ Barbara Nissman, Bartók and the Piano: A Performer's View, (Lanham, Md.: Scarecrow Press, Inc., 2002), x.

${ }^{66}$ József Ujfalussy, Béla Bartók, (Boston: Crescendo Publishing Company, 1972), 387.

${ }^{67}$ Ibid, 387-388.

${ }^{68}$ Barbara Nissman, Bartók and the Piano: A Performer's View, (Lanham, Md.: Scarecrow Press, Inc., 2002$), 9$.
} 
Europe. During this time, he started having serious health issues and was later diagnosed with a terminal illness. Bartók died of leukemia in 1945, in New York City.

Bartók’s catalogue of compositions includes works for solo piano; concertante works for piano; violin; viola; songs; choral works; orchestral and chamber works; two ballets; and one opera. His catalogue of piano compositions is large and includes transcriptions and pedagogical compositions. Among his most representative works for piano are the Sonata BB 88 (1926); Out of Doors (1926); Allegro Barbaro (1911); Mikrokosmos (1926, 1932-1939); Four Dirges Op. $9 b$ (1910); Sonata for Two Pianos and Percussion (1937); and the three Piano Concertos (1926, 1930-1931 and 1945). ${ }^{69}$

Pianist Barbara Nissman has done an extensive exploration of Bartók’s piano music. Her writings, recordings, lecture recitals, and master classes show her strong commitment to understanding and sharing the piano music of this great composer. Her major contributions include the book Bartók and the Piano: A Performer's View; the discovery and first recording of Bartók’s unpublished Piano Sonata from 1898; the recording of Bartók’s most representative solo piano works; and numerous lectures and performances in music schools and concert halls in the United States and the United Kingdom.

Barbara Nissman’s book, Bartók and the Piano: A Performer’s View (2002), represents a vital source of information for pianists and other musicians. Nissman provides information on Bartók’s major piano compositions with overviews, structural analysis, performance suggestions, and personal interpretations. She also briefly discusses the lesser-known piano compositions and transcriptions, and she examines Bartók as a pianist and teacher.

\footnotetext{
${ }^{69}$ Barbara Nissman, Bartók and the Piano: A Performer's View, (Lanham, Md.: Scarecrow Press, Inc., 2002), 296298.
} 


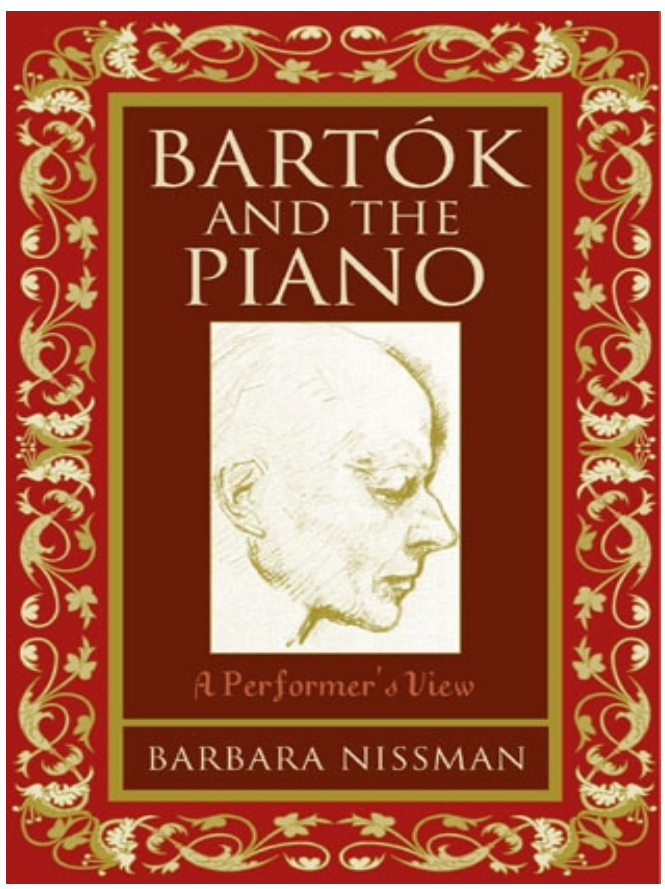

Figure 8. Cover Photo of Barbara Nissman's book Bartók and the Piano: A Performer's View (Scarecrow Press, 2002).

The idea of writing a book about Bartók’s piano music from the viewpoint of a pianist came to Nissman when she was preparing to record a CD of Bartók's piano music. She explains:

I was stunned to discover that Bartók’s piano output-a total of more than 300 works, including the 153 pieces from Mikrokosmos-had never been thoroughly discussed in print from the perspective in which the music had been conceived: at the piano and from the point of view of the performer. ${ }^{70}$

Bartók and the Piano: A Performer's View contains a full-length companion CD with recordings of selected pieces performed by Nissman. The CD accompanies the discussions of each chapter and further demonstrates Nissman’s explanations. This book has received the highest praise from prominent musicians and critics: ${ }^{71}$

\footnotetext{
${ }^{70}$ Barbara Nissman, Bartók and the Piano: A Performer's View, (Lanham, Md.: Scarecrow Press, Inc., 2002), x.

${ }^{71}$ Barbara Nissman, "Bartók and the Piano,” in Barbara Nissman, accessed October 20, 2018, https://www.barbaranissman.com/books-and-publications.
} 
Barbara Nissman's study and research translate into one of the most thorough examinations of one performer to another. This is an invaluable aid for professional, teacher and student alike.

\section{Leonard Slatkin}

In its finest case studies this book is brilliant. Nissman's book is... a triumph. It is well produced, with lavish musical examples, and a generally high level of accuracy.

\section{Malcolm Gillies}

Barbara Nissman's extraordinary pianistic and musical gifts coupled with her astute analytical perception of Bartók’s creative art makes for ideal authoritative equipment for the guidance of pianists in the study of Bartók’s great music.

\section{Rosalyn Tureck}

Also in this book, Nissman includes a discussion of an unpublished composition she discovered while researching Bartók’s piano music: the Piano Sonata from 1898. She found the manuscript as part of the Robert Owen Lehman Collection on deposit at the Pierpont Morgan Library in New York City. ${ }^{72}$ Nissman is credited with making the first recording of this unpublished composition which was issued by Pierian Recording Society in 2003.

In the same year, 2003, Nissman gave the first performances of the Sonata from 1898 together with lecture-recitals based on Bartók: A Performer's View in acclaimed concert halls and top music schools, including Steinway Hall in New York and London; Oxford University; Cambridge; Royal Academy of Music (UK); and the Hungarian Embassy in Washington, DC. ${ }^{73}$

When discussing this unpublished Sonata of 1898, Nissman explains in her book that it was written by a young Bartók (when he was only seventeen years old) and that it shows the influences of the great romantic composers. She says:

The opening movement has the heaviness of Brahms, the octaves of Liszt, and the pomposity of Wagner. This passage could have

\footnotetext{
${ }^{72}$ Barbara Nissman, Bartók and the Piano: A Performer's View, (Lanham, Md.: Scarecrow Press, Inc., 2002$), 2$.

${ }^{73}$ Barbara Nissman, Curriculum vitae.
} 
come from a Wagner opera or possibly have been extracted from one of Liszt's Transcendental Studies. ${ }^{74}$

The discovery and recording of this early composition provide a contrast with Bartók’s later style. After his formal studies at the Budapest Academy of Music, Bartók started to concentrate on what would become his lifelong work and legacy in the field of ethnomusicology. Nissman explains that "collecting folk music was his real passion and became the food for his compositions.” ${ }^{75}$ Bartók’s use of traditional music became a vital element in his music, but his compositional language considerably changed through the years. Nissman explains how the modal nature of the peasant's music called for new compositional techniques. ${ }^{76}$ Though Bartók’s music could be analyzed using various modern compositional systems, he opposed to fitting music into those methods. Nissman clarifies:

For Bartók, polytonality or atonality was nonexistent and impossible to achieve, except intellectually, because the ear naturally related every sound to those previously heard and then linked them together to a tonal center... Bartók was not a theorist; he was a pianist as well as a composer. He was a concert performer whose occupation relied mainly on his trained ears and his ability to listen. ${ }^{77}$

Barbara Nissman recommends that pianists (and musicians in general) keep in mind the following when studying the complexity of Bartók’s music:

The performer must find and follow the path the composer walked, discarding all preconceptions. Bartók forces the pianist to approach his music with an open mind, a flexible soul, and very good ears. ${ }^{78}$

\footnotetext{
${ }^{74}$ Barbara Nissman, Bartók and the Piano: A Performer's View, (Lanham, Md.: Scarecrow Press, Inc., 2002), 3.

${ }^{75}$ Ibid, 10.

${ }^{76}$ Ibid, 36 .

${ }^{77}$ Ibid, 37.

${ }^{78}$ Ibid, ix.
} 
Bartók’s piano music can be extremely difficult to decipher and even more so to perform. In fact, some of the most difficult piano compositions in the entire piano literature have been written by this composer. Nevertheless, Bartók was an exceptional pianist and, as Nissman explains, his pianistic nature always complemented his writing:

Bartók's compositional development never negates his natural pianism. Moreover, it is this solid keyboard foundation that allows him the freedom to transcend the instrument and go beyond the piano's musical limitations. ${ }^{79}$

Another essential characteristic of the music of Béla Bartók that Nissman examines in depth is the composer's precise indications to the performer. Bartók was a very detailed composer who left in the scores numerous musical, rhythmic, and tempo markings. In her book, Nissman provides valuable commentaries to help understand the markings in many of Bartók's piano compositions. Overall, she explains:

Bartók was meticulous in all of his markings; even metronomic markings and timings have been accurately noted. ${ }^{80}$

In 2014, Barbara Nissman was invited to participate in a symposium on Béla Bartók’s piano music that combined the commentaries of renowned musicians: Vladimir Ashkenazy, Peter Donohoe, Peter Frankl, Jenö Jandó, and Zoltán Kocsis. This symposium was led by Jeremy Siepmann and was published later that same year in an article for International Piano (UK) magazine. ${ }^{81}$ Some of Nissman's remarks published in this article further explain the challenge of interpreting Bartók’s markings:

\footnotetext{
${ }^{79}$ Barbara Nissman, Bartók and the Piano: A Performer's View, (Lanham, Md.: Scarecrow Press, Inc., 2002), 10.

${ }^{80}$ Ibid, xii.

${ }^{81}$ Barbara Nissman, Vladimir Ashkenazy, Peter Donohoe, Peter Frankl, Jenö Jandó, Zoltán Kocsis, and Jeremy Siepmann, "Symposium: Beyond Nationality," in International Piano, no. 24 (March-April 2014): 47-51.
} 
And all of Bartók’s instructions, in spite of their detailed markings, underline the improvisatory nature of the music. There's a romantic soul hiding behind all those many layers that need to be peeled away. There's colour, there's humour, and as you say, always that humanity. ${ }^{82}$

In addition, Nissman comments on the role of the performer in interpreting Bartók's indications:

Through musical taste and well-developed musical instincts, the performer should know how far to exercise freedom without compromising the music's character. That's essential. ${ }^{83}$

And for some of those tempo-marking challenges, she makes an interesting observation:

But Bartók himself admitted his metronome was faulty - and that's not just hearsay. In a letter to Max Rostal he writes 'In my earlier works, MM signs are often inexact, or rather they do not correspond to correct tempos. The only explanation I can think of is that I metronomised too hastily at that time, and perhaps my metronome was working imperfectly. ${ }^{, 84}$

When asked what advice she would give to young pianists studying the music of Béla Bartók,

Nissman responded:

For me Bartók is the twentieth century equivalent to Beethoven, and like Beethoven, his piano music sometimes goes beyond what the piano can do. It's as if he is not writing primarily for the instrument but just writing for the purity of the music. Its challenges are many: rhythmic, harmonic, pianistic. His scores must be analyzed and studied to truly understand their complexity. The brain must be able to decipher and organize every element to make sense out of these difficulties. Color, touch articulation, rhythm- all details are meticulously indicated in Bartók’s scores and should be duly noted. ${ }^{85}$

Barbara Nissman has also made a substantial contribution to the discography of Bartók’s piano literature. Her most celebrated recordings include Bartók by Nissman (2003) issued by

\footnotetext{
${ }^{82}$ Barbara Nissman, Vladimir Ashkenazy, Peter Donohoe, Peter Frankl, Jenö Jandó, Zoltán Kocsis, and Jeremy Siepmann, "Symposium: Beyond Nationality," in International Piano, no. 24 (March-April 2014): 49.

${ }^{83}$ Ibid: 51.

${ }^{84}$ Ibid: 51.

${ }^{85}$ Interview with Barbara Nissman. Answer sent by email on 10/14/18.
} 
Pierian Recording Society (which includes the first performance of the Sonata from 1898); Folk Music and More!: Music of Béla Bartók (2014); and Bartók’s piano pieces Out of Doors, BB 89 included in the album Out of Doors (2014). These last two CDs were issued by her own label, Three Oranges Recordings. The reviews of these recordings highlight Nissman's pianism and interpretation: ${ }^{86}$

Her commitment to every note is palpable, her pianistic command formidable, her psychologically penetrating emotional canvas revelatory, and her ability to combine eloquence with structural illumination is uncommon in every degree.

Piano (UK), 2006

Nissman makes as formidable an interpreter of Bartók as she was of Prokofiev and Ginastera in her previously issued set of their complete piano works. Her pianism matches the music's fantasy, elasticity and intensity, with no trace of percussive brittleness. I cannot imagine anyone playing any of it better.

John von Rhein - Chicago Tribune, 2003

Barbara Nissman's contribution to the study of Bartók’s piano music is invaluable. Her book provides assistance in facing the pianistic and interpretative challenges of the piano music of Bartók. And her recordings, lectures and articles promote the music of this extraordinary composer. Nissman’s own journey in understanding Bartók’s piano music will enlighten, encourage, and inspire future generations of pianists and other musicians. She explains:

The process of studying Bartók's piano music is quite similar to what a West Virginia farmer does with a chunk of wood in his hand. As one digs and chips away, the soul of this music slowly begins to emerge, and the work starts to take on its own shape. As Bartók himself said, every piece finds its own form. ${ }^{87}$

\footnotetext{
${ }^{86}$ Barbara Nissman, “Recordings: Bartók,” in Barbara Nissman, accessed October 20, 2018, https://www.barbaranissman.com/bartok.

${ }^{87}$ Barbara Nissman, Bartók and the Piano: A Performer's View, (Lanham, Md.: Scarecrow Press, Inc., 2002), 301.
} 


\section{CHAPTER IV}

\section{BARBARA NISSMAN ON FRANZ LISZT'S PIANO MUSIC}

It was Liszt who opened the door for others to follow. Franz Liszt, the celebrated "pop star" of his time, remains the musical "godfather" of all pianists. ${ }^{88}$

- Barbara Nissman

Hungarian pianist and composer Franz Liszt (1811-1886) revolutionized the musical traditions and tendencies of the Romantic Era. With his incredible virtuosity, his unusual use of the piano and his radical changes of the concert traditions, he became a controversial figure who was both admired and criticized. Nevertheless, Liszt inspired and influenced several of the great composers of the twentieth century and his music continues to amaze pianists and other musicians around the world.

Born in a German-speaking town in Hungary, Franz Liszt started taking piano lessons when he was seven years old with his father, Adam Liszt. ${ }^{89}$ In 1821 , the family moved to Vienna where Liszt took piano lessons with Carl Czerny and composition lessons with Antonio Salieri. After the death of his father in 1827, Liszt started to show growing interest and devotion to the Catholic Church. During the following years, Liszt toured throughout Europe giving concerts in France, Germany, England, Italy, Switzerland and Hungary. Liszt was known and admired for his generosity, constantly donating a large part of his earnings to the underprivileged and to various social causes. In fact, Liszt received the Hungarian Sword of Honour for his contributions to society in $1840 .{ }^{90}$ Franz Liszt also revolutionized the musical traditions of the

\footnotetext{
${ }^{88}$ Barbara Nissman, Liszt: The Transcendentals, CD, Three Oranges Recordings, 2017, Booklet, 1.

${ }^{89}$ Kenneth Hamilton, ed., The Cambridge Companion to Liszt, Cambridge Companions to Music, (Cambridge: Cambridge University Press, 2005), xii.

${ }^{90}$ Ibid, xiii.
} 
nineteenth century. He is credited for changing the position of the piano on stage (with the pianist playing sideways in profile), for inspiring enhancements of the instrument, for creating the modern solo recital, for establishing the tradition of playing from memory, and for introducing the concept of the modern virtuoso performer. In 1847, Liszt abandoned the touring career and concentrated on teaching, composing and reading. He taught numerous piano students and later established the tradition of group lessons in which the students could also learn from one another. ${ }^{91}$ Later in life and following his religious beliefs, Liszt took minor orders in the Catholic Church. Franz Liszt died in 1886 in Bayreuth, Germany.

Liszt's catalogue of compositions includes one opera; orchestral works; sacred and secular choral works; chamber music; organ pieces; songs; and other vocal works. Among his numerous piano compositions, his most famous are Années de Pèlerinage; Hungarian Rhapsodies; Etudes d'exécution Transcendante; Sonetti di Petrarca; Piano Concertos 1 and 2; Totentanz; and the Sonata in B minor.

For pianist Barbara Nissman, Franz Liszt is one of the most extraordinary, influential and misunderstood composers of all times. Many of Nissman's concerts, master classes, lectures and discography include the piano music of Liszt. Among her most important contributions are the CD Liszt by Nissman issued by Pierian Recording Society in 2002 (later reissued by Three Oranges Recordings in 2014) and the CD Liszt: The Transcendentals issued by Three Oranges Recordings in 2017. In addition, the DVD for children Franz Liszt: The Elvis of the Keyboard (2008) and the DVD Franz Liszt: Portrait of the Man \& His Masterwork - The Sonata in B Minor (2016) offer fascinating educational material for a variety of audiences. Nissman explains the significance of Liszt's legacy:

\footnotetext{
${ }^{91}$ Barbara Nissman, Franz Liszt: Portrait of the Man \& his Masterwork - The Sonata in B minor, DVD, 2 vols., Three Oranges Recordings, 2016. Disc I, Chapter IV, Part 2.
} 
After reading his many letters, plus every flattering and nonflattering biography written about him, and immersing myself in his piano music, I am happy to report that the spirit of Franz Liszt is alive and well. Even today his words and his music remain timely and relevant. ${ }^{92}$

The DVD Franz Liszt: The Elvis of the Keyboard (2008) is an enjoyable and didactic presentation for children. This project was created by Nissman and produced by the Greenbrier Valley Theatre with the support of the West Virginia Arts Commission and the National Endowment for the Arts. The video was filmed at Carnegie Hall in Lewisburg, West Virginia and features actors from the Greenbrier Valley Theatre (characterizing Chopin, Paganini, George Sand and Wagner) and a live audience of young children participating with questions and comments. ${ }^{93}$ This DVD was later distributed to schools and libraries in the state of West Virginia. Nissman explains the purpose of this educational project:

In an age when arts education is facing numerous challenges, this DVD provides an entertaining and informative solution. Music lifts the spirit and touches the heart and soul and can be accessible to all who listen. ${ }^{94}$

An extraordinary DVD created by Barbara Nissman is Franz Liszt: Portrait of the Man \& his Masterwork - The Sonata in B Minor issued by Three Oranges Recordings in 2016. This is a set of two DVDs. In the first DVD, Nissman includes a unique biographical account of the life of Franz Liszt told through letters written by the composer and his contemporaries. Nissman describes how this project was created:

\footnotetext{
${ }^{92}$ Barbara Nissman, "Living with Franz Liszt: September 6, 2016" in Piano Connections with Barbara (blog). Three Oranges Recordings, accessed October 20, 2018, https://threeorangesrecordings.com/blog/blog/living-with-franzliszt-september-6-2016.

${ }^{93}$ Barbara Nissman, "Barbara \& Friends: DVD Info," in Barbara Nissman, accessed October 20, 2018, https://www.barbaranissman.com/dvd-info.

${ }^{94}$ Ibid.
} 
After reading Liszt's letters, I decided to tell his story using only his words and the words of his contemporaries. Liszt suffered so much within his lifetime, and I believe that even today, he remains a man misunderstood - not only musically but also personally. ${ }^{95}$

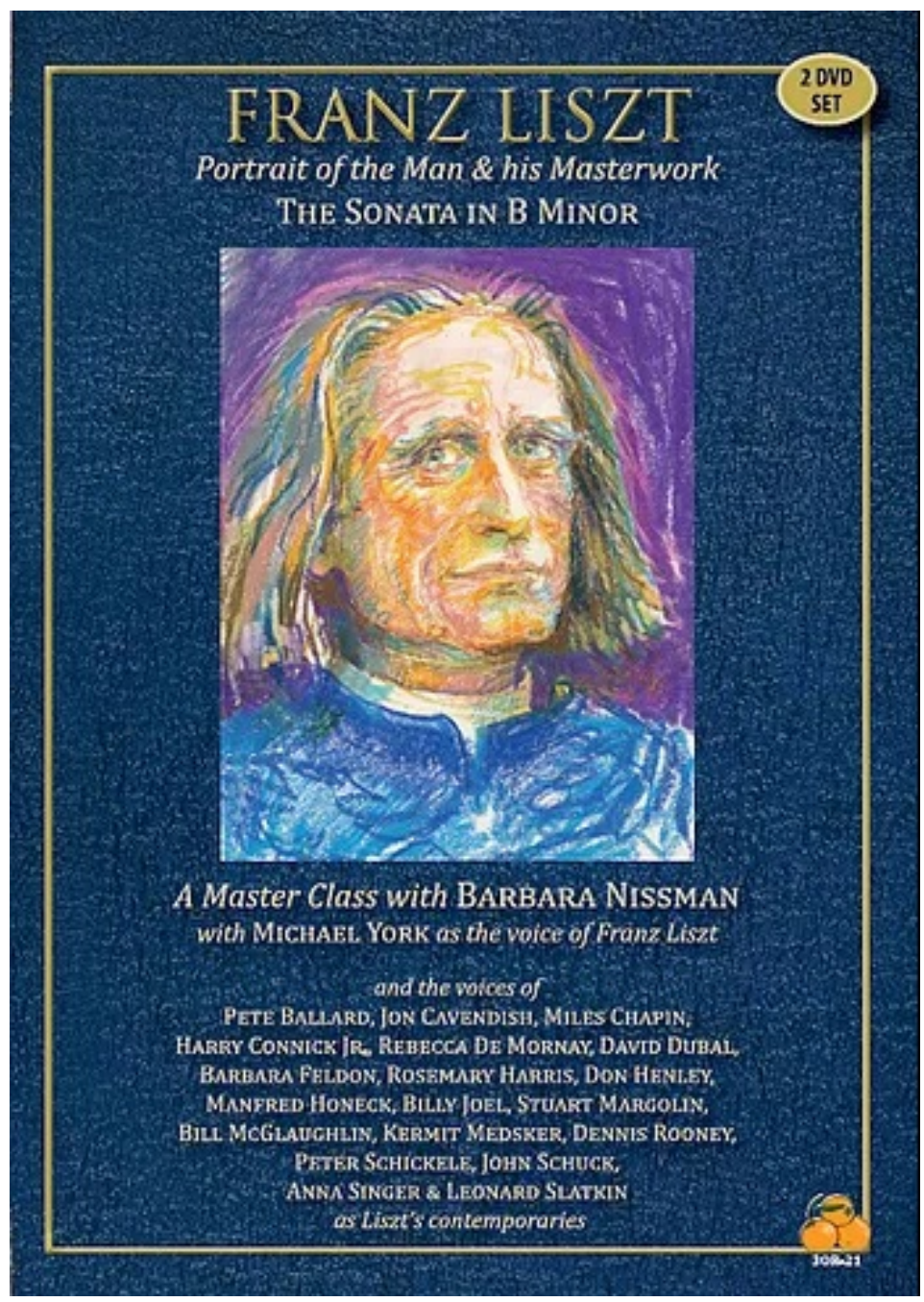

Figure 9. Cover Photo of DVD Franz Liszt: Portrait of the Man \& his Masterwork - The Sonata in B Minor (Three Oranges Recordings, 2016).

\footnotetext{
${ }^{95}$ Barbara Nissman, "Living with Franz Liszt: September 6, 2016,” in Piano Connections with Barbara (blog). Three Oranges Recordings, accessed October 20, 2018, https://threeorangesrecordings.com/blog/blog/living-withfranz-liszt-september-6-2016.
} 
The words of Franz Liszt and his contemporaries are read by famous actors and musicians who give voice to the main characters of the story: Chopin, Brahms, Czerny, Robert and Clara Schumann, Beethoven, Wagner, Berlioz, Grieg, and Strauss, among others. In her DVD, Nissman explains that "actor Michael York portrays Liszt as an old man looking back on his extraordinary life. A portrait emerges of a deeply spiritual and profoundly religious and vulnerable human being." 96 The voices of Liszt’s contemporaries come from many famous musicians including Billy Joel, David Dubal, Manfred Honeck, Pete Ballard, Leonard Slatkin, Don Henley, Harry Connick Jr., Rebecca de Mornay, Bill McGlaughin, Rosemary Harris, Barbara Feldon, Peter Schickele, John Schuck, and Anna Singer ,among others.

The second DVD in the set from Franz Liszt: Portrait of the Man \& His MasterworkThe Sonata in B Minor is a master class on Liszt's famous Sonata in B minor (1853). This DVD is divided into two sections: an in-depth historical and musical analysis of the Sonata in B minor and a concert performance of the work by Barbara Nissman. Nissman divides the master class in several categories: an introduction; context of the work; dedication of the work; meaning of the work; form; thematic transformation; key relationships; coda; dramatic devices; pacing the climaxes; virtuosity and pianism; technical problems; and the message of the Liszt Sonata. ${ }^{97}$ Nissman considers the Sonata in B minor to be Liszt's most demanding composition. She writes:

It challenges us on every level: emotionally it covers such a wide range; intellectually, the complexities of its form must be understood and all the pieces must be made to fit together in order to shape the work; physically, it taxes even the stamina and strength of the most experienced virtuoso performer. But most importantly and most demanding are its spiritual requirements, for this music to truly touch the soul, Liszt asks us to uncover all the layers so we can arrive at the essence of what I believe to be

\footnotetext{
${ }^{96}$ Barbara Nissman, Franz Liszt: Portrait of the Man \& his Masterwork - The Sonata in B minor, DVD, 2 vols., Three Oranges Recordings, 2016, Case.

${ }^{97}$ Ibid, Disc II: Menu.
} 
Liszt's confessional that he wrote for his favorite instrument... It is a vehicle for rediscovering... not only discovering what is new in Liszt's music but what is new in ourselves. ${ }^{98}$

Through the master class, Nissman plays examples on the piano to further explain her analysis. Of particular interest is her advice on how to play the difficult octave passages, the use of pedal and how to memorize the work by having a clear understanding of the form and structure. Concerning the message that Liszt delivers in this sonata, Nissman explains:

I do believe it is the journey of his soul and his complex relationship with God. He cries, he weeps, he shakes his fist in anger; but ultimately he accepts and is spiritually renewed. And he makes us feel this in the final bars. We really do feel the ascent of his soul to a higher place. ${ }^{99}$

Nissman’s DVD set on Liszt's life and work provides pianists and other musicians with a unique understanding of this extraordinary composer. Nissman’s biography of Liszt explained through letters delivers a genuine image of the composer, and her master class on the Sonata in $B$ minor is a revelatory analysis of the masterwork. The International Piano (UK) magazine awarded five stars to this DVD and praised Nissman's interpretation in a review:

Most of all, in her own concluding performance of the Sonata her playing shows a burning commitment and a special capacity to pass on the glory of Liszt's masterpiece. This DVD set is a vital tool to understanding. ${ }^{100}$

International Piano (UK), 2017

\footnotetext{
${ }^{98}$ Barbara Nissman, Franz Liszt: Portrait of the Man \& his Masterwork - The Sonata in B minor, DVD, 2 vols., Three Oranges Recordings, 2016, Disc II: Introduction. Words transcribed from DVD by author.

${ }^{99}$ Barbara Nissman, Franz Liszt: Portrait of the Man \& his Masterwork - The Sonata in B minor, DVD, 2 vols., Three Oranges Recordings, 2016, Disc II: What is the message of the Liszt Sonata?. Words transcribed from DVD by author.

${ }^{100}$ Bryce Morrison, “Reviews CDs \& DVDs,” International Piano, July-August 2017: 67.
} 
When asked what advice she would give to young pianists studying the music of Franz Liszt,

Nissman responded:

Liszt is the master of the keyboard and truly laid the foundation for grand bravura pianism. He opened the door for others to follow and influenced so many other composers: Rachmaninoff, Prokofiev, Ravel, Scriabin, Wagner, Ginastera, etc. He loved the instrument and knew how to write for it. No matter how difficult the writing might sound, it's always pianistic and fits comfortably under the hands. He uses the piano like an orchestra. Studying the pianism of Liszt and how he approaches the keyboard should be a requirement for every pianist. I strongly believe that his music needs to be played with joy - with ease - with facility and always with a romantic flair. The performer needs to revel in the glories of the piano and the persona of Liszt the supreme virtuoso! ${ }^{101}$

One outstanding recording of Barbara Nissman is the CD Liszt by Nissman (2003) which includes not only the Sonata in B minor; but also the Spanish Rhapsody; the Consolation No.3; and Six Paganini Etudes. Another magnificent CD is Liszt: The Transcendentals (2017) which includes the Twelve Transcendental Etudes, Funérailles and Valse Oubliée No. 1 in F\# minor. Some exceptional reviews of these recordings include: ${ }^{102}$

Here is a Liszt player of superior gifts.

Music Opinion (UK), June 2003

A Liszt disc by pianist Barbara Nissman shows her at the height of her interpretative powers.

Turok’s Choice, April 2003

Barbara Nissman not only admires Liszt, understands him, but she is one of the few great Liszt players in the world.

David Dubal, 2017

\footnotetext{
${ }^{101}$ Interview with Barbara Nissman. Answer sent by email on 10/14/18.

102 Barbara Nissman, "Recordings: Liszt," in Barbara Nissman, accessed October 20, 2018, https://www.barbaranissman.com/liszt.
} 
Barbara Nissman’s extensive research on the life and work of Franz Liszt has led her to create unique and inspiring DVDs which offer helpful information to better understand Liszt and his music. Nissman’s recordings, master classes, lectures, and concerts have equally contributed to the study of Liszt - as a person, composer, and pianist - and to the performance of his music.

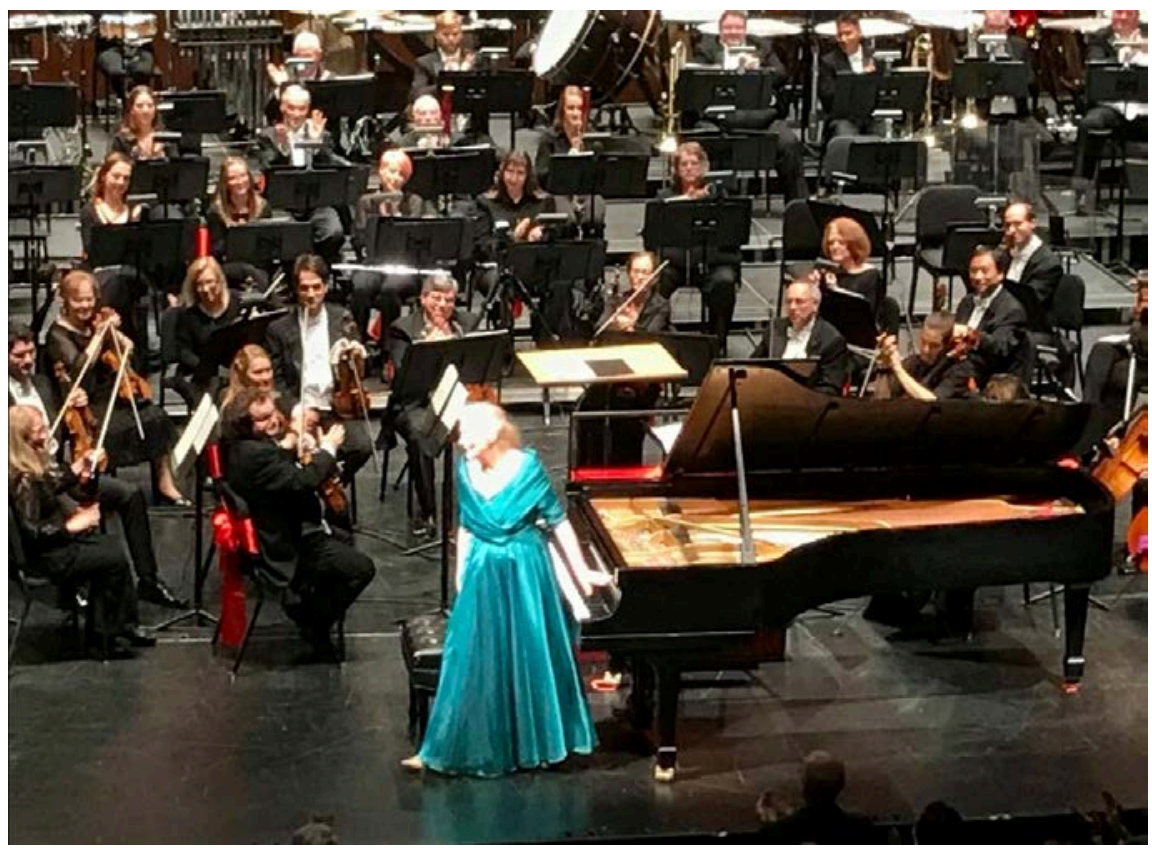

Figure 10. Barbara Nissman performance of Liszt's Totentanz with the West Virginia Symphony Orchestra conducted by Lawrence Loh on May $5^{\text {th }}, 2018$. 


\section{CHAPTER V}

\section{BARBARA NISSMAN ON SERGEI PROKOFIEV'S PIANO MUSIC}

I have always been attracted to Prokofiev's very personal brand of pianism. Francis Poulenc rightly nicknamed him the "Russian Liszt," and certainly no other major composer of the twentieth century has demonstrated such an extroverted acrobatic approach to keyboard virtuosity nor produced such a substantial piano repertoire. ${ }^{103}$

- Barbara Nissman

Russian composer, pianist, and conductor Sergei Prokofiev (1891-1953) is recognized as one of the most significant and yet controversial composers of the twentieth century. Sergei Prokofiev was born in Sontsovka, Ukraine, where he started his early formal musical training in piano and composition with Reinhold Glière. Later, in 1904, Prokofiev and his mother moved to St. Petersburg when he was accepted at the St. Petersburg Conservatory. Among his most important music teachers were Nikolai Rimsky-Korsakov, Nikolai Tcherepnin, Alexander Winkler, and Anatoly Lyadov. ${ }^{104}$ As a student and young musician, Prokofiev's style was harshly criticized many times. In 1913, during the premiere of his Second Piano Concerto Op. 16 performed by Prokofiev himself at Pavslovsk, St. Petersburg, members of the audience yelled "The devil take all this Futuristic music!... We can hear music like this from our cats at home.” ${ }^{105}$ Sergei Prokofiev left Russia in 1918 to try to find a more successful career outside his homeland. He first moved to New York in 1918, later to Germany in 1922 and to Paris in 1923. However, Prokofiev was fearful of losing his own musical voice and decided to move back to

\footnotetext{
${ }^{103}$ Barbara Nissman, Prokofiev by Nissman, CD. 3 vols., Pierian Recordings Society, 2001, Booklet, 1.

${ }^{104}$ Harlow Robinson, Sergei Prokofiev: A Biography, (Boston: Northeastern University Press, 2002), 46-64.

${ }^{105}$ Ibid, 96.
} 
Russia in 1936 to rediscover his own compositional language. ${ }^{106}$ Prokofiev received several Stalin Prizes for his compositions and a Lenin prize in 1957 (posthumously) for his Seventh Symphony, Op. $131 .{ }^{107}$ Sergei Prokofiev died in Moscow in 1953 after suffering increasing health issues triggered by a concussion he received in a fall in $1945 .{ }^{108}$ Prokofiev's catalogue of compositions includes operas; ballets; symphonies; orchestral works; incidental music; chamber music; concertos for piano; vocal/choral music; chamber music; and instrumental music for piano; violin; cello; and flute. Prokofiev's catalogue of piano music is vast. In fact, one third of his compositions are written for the keyboard. ${ }^{109}$ Among his most famous piano compositions are the nine Piano Sonatas; the five Piano Concertos; Sarcasms Op. 17; Visions Fugitive Op. 22; Four Pieces Op. 4; and the Toccata Op. $11 .^{110}$

Pianist Barbara Nissman is recognized worldwide as a leading expert in the piano music of Sergei Prokofiev. She made history in 1989 when she became the first pianist to perform Prokofiev's complete piano sonatas in a series of three recitals in New York and London. In preparation for these concerts, Nissman received a grant from IREX (Institute for Research and Exchanges Board) in 1988 to travel to Russia and research Prokofiev's manuscripts at the Central State Archives in Moscow. The following year, she received a two-page fragment of the Piano Sonata No. 10, Op. 137 from the Soviet Union in time for its premiere in her historical recitals of Prokofiev's complete piano sonatas. These concerts were held in 1989 at Alice Tully Hall - Lincoln Center in New York and Wigmore Hall in London. ${ }^{111}$

\footnotetext{
${ }^{106}$ Barbara Nissman, Vladimir Ashkenazy, Murray McLachlan, Frederic Chiu, Boris Berman, and Jeremy Siepmann, “Symposium: Shakespearean Sage or Soviet Court Jester?” in International Piano, no. 20 (July-August 2013): 31.

${ }^{107}$ Harlow Robinson, Sergei Prokofiev: A Biography, (Boston: Northeastern University Press, 2002), 490.

${ }^{108}$ Ibid, 543.

${ }^{109}$ Barbara Nissman, Prokofiev by Nissman, CD. 3 vols., Pierian Recordings Society, 2001, Booklet, 1.

${ }^{110}$ Harlow Robinson, Sergei Prokofiev: A Biography, (Boston: Northeastern University Press, 2002), 545-554.

${ }^{111}$ Barbara Nissman, Curriculum vitae.
} 


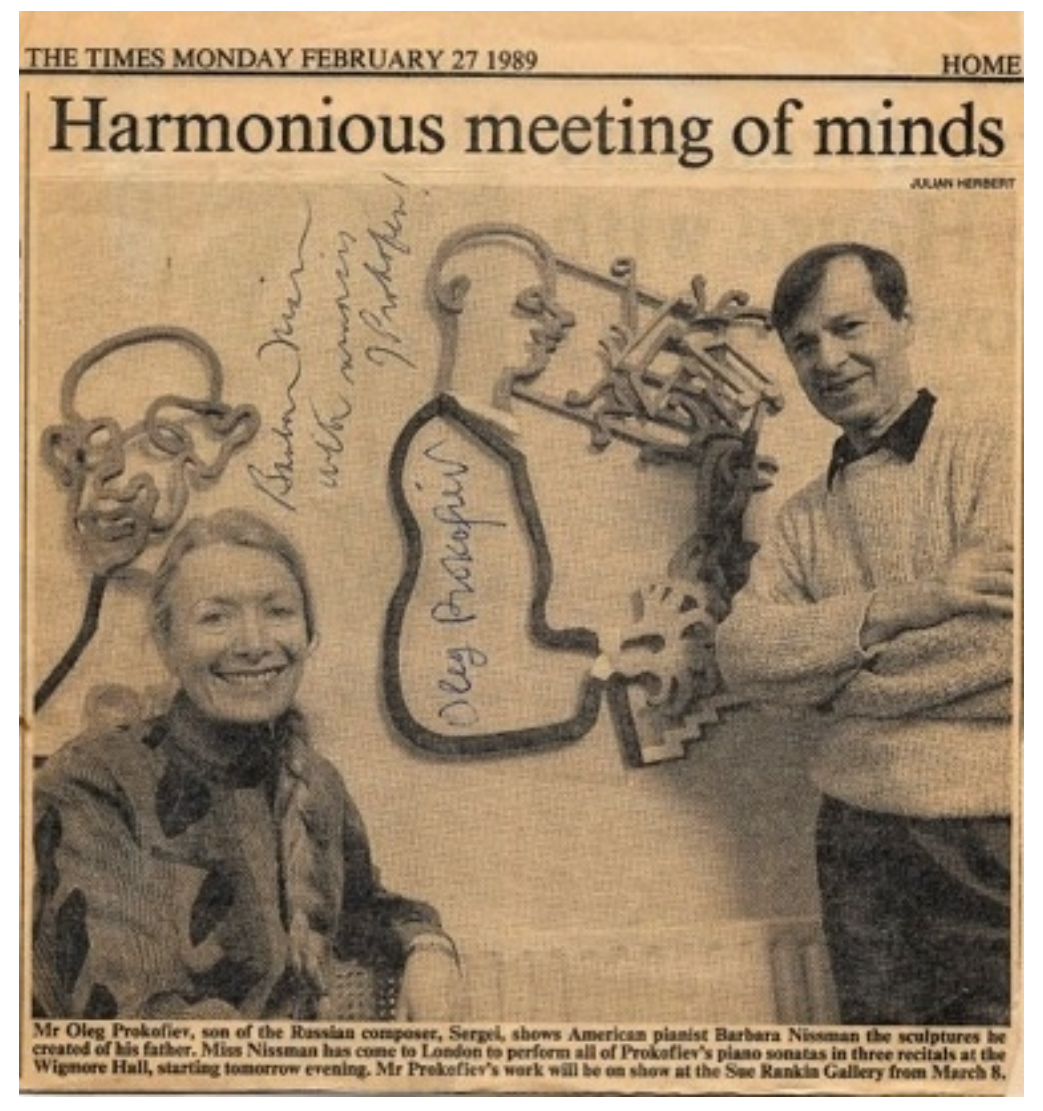

Figure 11. Barbara Nissman and Oleg Prokofiev (son of Sergei Prokofiev) a day before Nissman's historical recital series at Wigmore Hall in London (1989).

Photo published in The Times, London.

To celebrate the $100^{\text {th }}$ anniversary of Prokofiev's birth in 1991, Nissman performed again the entire series of piano sonatas throughout Europe and the United States. During this tour, and in conjunction with the Dutch Radio, she gave the first live performances of the complete piano sonatas throughout Holland. ${ }^{112}$

Also in 1989, Nissman recorded the complete piano sonatas and other major works of Sergei Prokofiev in a set of three CDs. This CD set includes the two versions of the Sonata No. 5, Op. 38 and Op. 38/135 (written in 1923 and revised in 1952-53) and the fragment of the Sonata No. 10, Op. 137. Nissman became the first pianist to make this significant repertoire

112 Barbara Nissman, Curriculum vitae. 
available on compact disc. This CD set was issued by Newport Classic label and released in

1989. Later, these recordings were reissued by the Pierian Recording Society (2001) and by

Three Oranges Recordings (2014). The reviews of these albums highly praise Nissman's pianism and interpretation: ${ }^{113}$

Nissman brings to these fascinating sonatas an all-too-rare combination of stunning technique and unmistakable thoughtfulness. A significant release and a must for anyone with an interest in Russian piano music, $20^{\text {th }}$ century piano music, or just great piano playing.

American Record Guide, 2003

Miss Nissman's playing is full of wit and bite, of dramatic shadings and crisps characterizations... Sufficient to say that her interpretations of these larger works are replete with atmosphere and imagination, of astringency, brittleness, and extreme digital clarity.

Rachmaninoff Society Newsletter, 2004

This is big, luscious, rhapsodic and often electrifying playing in the great Romantic tradition of Liszt, Rubinstein, Carreño, Horowitz and Argerich... This is not only a truly great virtuoso but a deeply intelligent and thinking one.

Piano (UK), 2003

Her intellectually rigorous focus allows few interpretive eccentricities, and the technical command is formidable... the wilder the explosive force the more thankful one is for Nissman's lucidity. There is one truly great performance of the Seventh Sonata; not even Pollini has a stronger grip on its unquiet spirit.

BBC Music Magazine, 2002

${ }^{113}$ Barbara Nissman, "Recordings: Prokofiev,” in Barbara Nissman, accessed October 25, 2018, https://www.barbaranissman.com/prokofiev. 


\section{PROKOFIEV by NISSMAN}

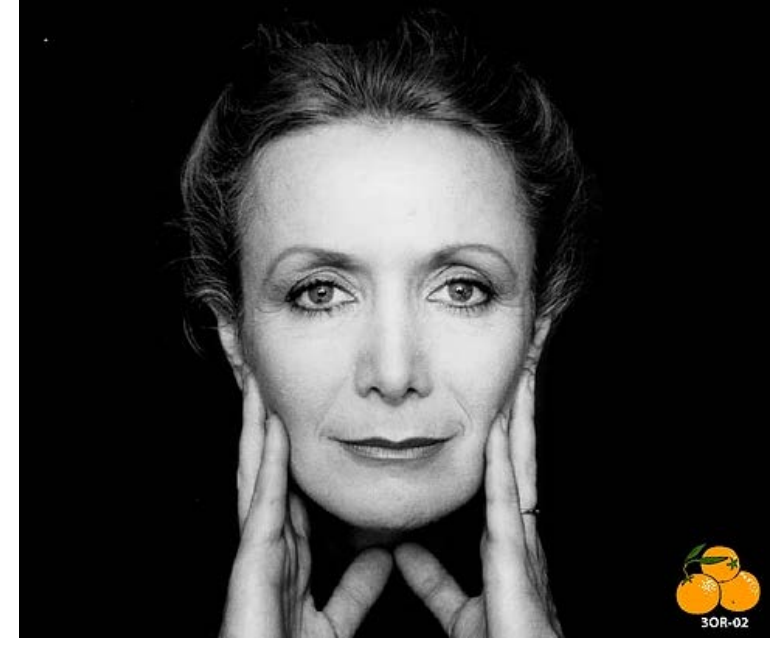

Figure 12. Cover Photo of CD Prokofiev by Nissman (Three Oranges Recordings, 2014).

Barbara Nissman’s extensive study of Prokofiev's piano music has made her a muchadmired specialist around the world. In 1998, she was invited to give master classes and lectures on Prokofiev's piano music at the Moscow Conservatory and the St. Petersburg Conservatory. ${ }^{114}$ In 2003, together with Ashkenazy and Rostropovich, she participated in a BBC World Service interview about the music of Prokofiev. This interview was aired on BBC Radio 3 in honor of the $50^{\text {th }}$ anniversary of the composer's death. ${ }^{115}$ In 2004, Nissman gave a lecture entitled Gershwin Meets Prokofiev: Prokofiev meets Gershwin in the symposium "Prokofiev in America” held at the University of London. Other titles of her lecture recitals include: An evening with Barbara \& Her “Friend” Prokofie; Prokofiev \& Lisz; Prokofiev \& Bartók; Prokofiev \& the Russian; The Complete Piano Sonatas; and The Five Piano Concertos. ${ }^{116}$

\footnotetext{
${ }^{114}$ Barbara Nissman, Curriculum vitae.

${ }^{115}$ Ibid.

${ }^{116}$ Barbara Nissman, "Prokofiev Lectures: Lecture Recitals," in Barbara Nissman, accessed October 25, 2018, https://www.barbaranissman.com/lecture-recitals.
} 
In memory of the $50^{\text {th }}$ anniversary of Prokofiev's death in 2003, Nissman performed all five piano concertos in concerts throughout Europe and the United States. ${ }^{117}$ More recently, in April 2015, Nissman was invited to perform at the dedication ceremony for the opening of the Prokofiev Archive at Columbia University in New York City. This archive was originally held at the Goldsmith College - University of London but was moved to the United States after it was acquired by Columbia University. Some of the remaining Prokofiev family attended this important event. ${ }^{118}$

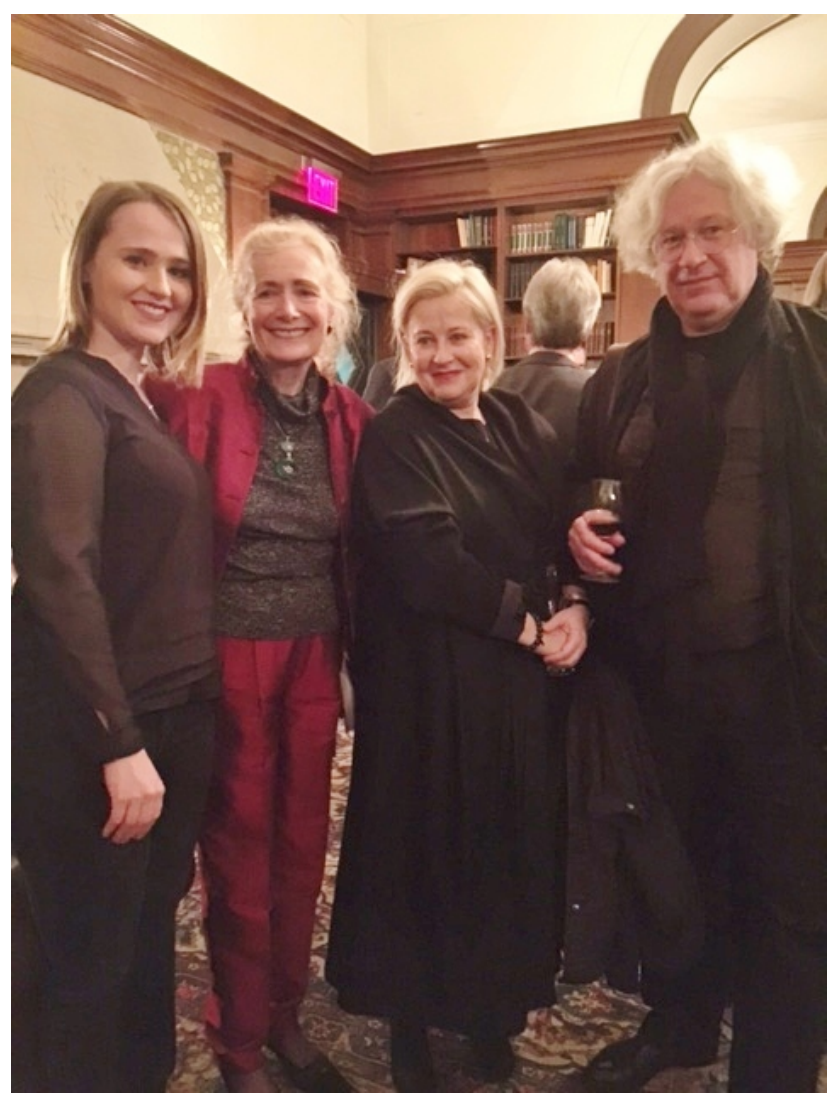

Figure 13. Barbara Nissman together with Sviatoslav Prokofiev (grandson of Sergei Prokofiev) and his family at the Prokofiev Archive dedication at Columbia University in New York City on April 24 $4^{\text {th }}, 2015$.

\footnotetext{
${ }^{117}$ Barbara Nissman, Curriculum vitae.

118 "Music of Serge Prokofiev,” Columbia University - The Italian Academy for Advanced Studies in America, accessed October 30, 2018, http://italianacademy.columbia.edu/event/music-serge-prokofiev.
} 
Pianist Barbara Nissman has also written several articles about the piano music and compositional style of Prokofiev for renowned music magazines including Keyboard Classics, Musical Opinion (UK), Musical Time (UK), Piano Today, Three Oranges Journal, and Piano (UK). One important article written by Nissman is "The Many Faces of Prokofiev: As seen through his Piano Concertos.” This article written in 2002 and published in Three Oranges Journal, provides an extensive analysis of each of the five piano concertos and offers useful observations for musicians and performers. ${ }^{119}$ In 2013, Nissman participated in a provocative symposium on Prokofiev’s piano music entitled “Shakespearean Sage or Soviet Court Jester?” This symposium was led by Jeremy Siepmann and was published in an article for International Piano (UK) magazine. ${ }^{120}$ Also included in this article are the commentaries and observations by prominent pianists: Vladimir Ashkenazy, Murray McLachlan, Frederic Chiu, and Boris Berman.

One of Nissman's most interesting writings on Prokofiev's piano music is a book chapter entitled “Sergei Prokofiev: A Man Misunderstood” included in the book The Pianist’s Craft: Mastering the Works of Great Composers published by Scarecrow in 2012. ${ }^{121}$ Nissman explains in her book chapter how the life and music of Sergei Prokofiev has been deeply misinterpreted through the years. Undeniably, Prokofiev was a composer who suffered severe criticism during his life. His personality was considered arrogant and opinionated making many people uncomfortable. He was also criticized by his Russian contemporaries for leaving his homeland and later returning in 1936 (Prokofiev's name was subsequently linked to the leader Josef

\footnotetext{
${ }^{119}$ Barbara Nissman, “The Many Faces of Prokofiev: As seen through his Piano Concertos,” in Three Oranges Journal, November 2002 issue, accessed October 31, 2018, http://www.sprkfv.net/journal/three04/manyfaces5.html. ${ }^{120}$ Barbara Nissman, Vladimir Ashkenazy, Murray McLachlan, Frederic Chiu, Boris Berman, and Jeremy Siepmann, “Symposium: Shakespearean Sage or Soviet Court Jester?” in International Piano, no. 20 (July-August 2013): 29-33.

${ }^{121}$ Barbara Nissman, "Sergei Prokofiev: A Man Misunderstood," in The Pianist's Craft: Mastering the Works of Great Composers, ed. Richard P. Anderson, (Lanham, Md.: Scarecrow Press, 2012), 189-200.
} 
Stalin). ${ }^{122}$ And musically, Prokofiev was rigorously critiqued during his lifetime. Even today,

Prokofiev continues to receive mixed reactions among listeners and performers as Nissman

describes in her writings:

I think he's been misunderstood not only musically but also personally, politically and pianistically. The trouble we have with his music is that it defies categorization. For some listeners, he's too old-fashioned, too dated and conservative; for others, his dissonance and 'modernism' can still be very uncomfortable...Pianistically, Prokofiev’s music has frequently been misunderstood by performers and audiences. His piano music has been perceived by many as cold, brittle, angry and 'only technique. ${ }^{123}$

Nissman’s book chapter, “Sergei Prokofiev: A Man Misunderstood” offers a fascinating exploration of the musical elements in Prokofiev's piano music. Nissman divides her analysis based on how Prokofiev examined his own music. In addition, she includes a vital element as she further explains:

Prokofiev himself outlines five major trends that characterize his style and are essential to an understanding of his work: the classical structure, the lyrical line, the search for a personal and modern harmonic language, the rhythmic toccata element, and a sense of play. To complete Prokofiev's list, I would add another important ingredient: the element of virtuosity and pianism. ${ }^{124}$

In analyzing the classical structure in Prokofiev's music, Nissman examines closely the set of piano sonatas. She describes Prokofiev's development in the use of this musical form:

\footnotetext{
${ }^{122}$ Barbara Nissman, "Sergei Prokofiev: A Man Misunderstood," in The Pianist's Craft: Mastering the Works of Great Composers, ed. Richard P. Anderson, (Lanham, Md.: Scarecrow Press, 2012), 189-190.

${ }^{123}$ Barbara Nissman, Vladimir Ashkenazy, Murray McLachlan, Frederic Chiu, Boris Berman, and Jeremy Siepmann, “Symposium: Shakespearean Sage or Soviet Court Jester?” in International Piano, no. 20 (July-August 2013): 31.

${ }^{124}$ Barbara Nissman, "Sergei Prokofiev: A Man Misunderstood," in The Pianist’s Craft: Mastering the Works of Great Composers, ed. Richard P. Anderson, (Lanham, Md.: Scarecrow Press, 2012), 191.
} 
Like Beethoven's thirty-two sonatas, Prokofiev's nine piano sonatas chart the chronology of his personal journey with the sonata form. Similar to Beethoven before him, Prokofiev stretched the form's parameters, exploited its dramatic possibilities, and then reached the summit with the three War Sonatas, his masterworks for the keyboard. ${ }^{125}$

When approaching Prokofiev's piano music, Nissman emphasizes the importance of discovering the lyrical line:

Even in his most complex compositions, the key to understanding where he is headed is to just follow the melodic line. It will never disappear or disappoint. He might occasionally surround and disguise it with lots of bravura pianism, but just look a little closer: the melody is always there; it always remains part of the basic skeleton. ${ }^{126}$

In deciphering Prokofiev's piano music, Nissman also recommends pianists to uncover the harmonic language to truly understand the music:

Even the thorniest dissonant-sounding passages can be reduced to a traditional harmonic skeleton of tonic, subdominant, and dominant harmonies once his personal vocabulary is understood. ${ }^{127}$

And a key element in Prokofiev's music that must be brought out is his sense of humor, wit and sarcasm. According to Nissman:

Sometimes Prokofiev's humor can be quite cold and biting, sometimes slapstick, sometimes sadly touching. He has lots of imagination and a wonderful sense of the fantastic world! ${ }^{128}$

In an interview, Barbara Nissman was asked what advice she would give to young pianists studying the music of Sergei Prokofiev. Nissman responded:

Prokofiev is definitely the "Russian Liszt" as nicknamed by Poulenc. With his athletic pianism, he makes the performer jump

\footnotetext{
${ }^{125}$ Barbara Nissman, "Sergei Prokofiev: A Man Misunderstood," in The Pianist's Craft: Mastering the Works of Great Composers, ed. Richard P. Anderson, (Lanham, Md.: Scarecrow Press, 2012), 191.

${ }^{126}$ Ibid, 195.

${ }^{127}$ Ibid, 196.

${ }^{128}$ Ibid, 198.
} 
through all sorts of hoops, pianistically speaking, and virtuosity is an essential part of his musical language. When all the notes are mastered and all the layers peeled away, he leaves us with beautiful melodies using traditional harmonies and a strong sense of form and structure. And how well he writes for the piano! Attention should also be paid to his strong wit and sense of humor, frequently overlooked in his piano music. ${ }^{129}$

She further explains:

Performing Prokofiev's music requires tremendous energy and stamina in combination with a well-coordinated and relaxed technique. Without all of these ingredients, it is impossible to bring Prokofiev's music to life and perform it with the joy and abandon that it deserves. ${ }^{130}$

Barbara Nissman’s remarks on the piano music of Sergei Prokofiev are highly respected among specialists. In February 2016, she was a featured performer in the international symposium Prokofiev and the Russian Tradition held at Louisiana State University. This symposium featured eminent scholars and musicians including Richard Taruskin, Simon Morrison, Natalia Navkina, and pianist Frederic Chiu. More recently, in April 2018, Nissman participated in the symposium New Directions in Prokofiev Studies held at Columbia University in New York. On this occasion, Nissman gave a fascinating lecture entitled The Three Fifths: Prokofiev's Fifth Piano Sonatas \& Fifth Piano Concerto: A Performer's View. ${ }^{131132}$

Nissman is currently working on two substantial projects dedicated to Sergei Prokofiev and his piano compositions. The first project is a book on Prokofiev's piano music that will offer an in-depth exploration of his piano repertoire. This book will be titled Prokofiev \& the Piano: A Performer's View. And her second project is a DVD presenting the life and work of Sergei

\footnotetext{
${ }^{129}$ Interview with Barbara Nissman. Answer sent by email on 10/14/18.

${ }^{130}$ Barbara Nissman, "Sergei Prokofiev: A Man Misunderstood,” in The Pianist's Craft: Mastering the Works of Great Composers, ed. Richard P. Anderson, (Lanham, Md.: Scarecrow Press, 2012), 198.

${ }^{131}$ Barbara Nissman, email message to author, April 11, 2018.

${ }^{132}$ The Three Fifths refers to the Piano Sonata No. 5, Op. 38 (first version of 1923); the Piano Sonata No. 5, Op. 38/135 (second version of 1952-53) and the Piano Concerto No. 5, Op. 55.
} 
Prokofiev. ${ }^{133}$ This DVD will be the third one in her educational DVD series created with the purpose of providing a better understanding of these exceptional composers and making them accessible to all audiences.

Barbara Nissman provides musicians a deeper understanding of the essential elements in Prokofiev's music. Her writings and lectures help liberate audiences from the many misconceptions and stereotypes that have shadowed this composer for decades. Her recordings, considered as definitive by several critics, truly inspire and motivate the listener to discover the music of this extraordinary composer. Nissman expresses her views on Prokofiev’s compositional style and her own experience playing Prokofiev’s piano music:

Prokofiev discovered a way to attach the present to the future while building on the past. By juxtaposing familiar things in unfamiliar ways, he creates something fresh, new, and spontaneous: a very personal musical language that is completely his own... Prokofiev challenges the performer to go beyond virtuosity and try to peel away the many layers that cover his hidden soul... Every time I perform the music of Prokofiev, I feel his joy in playing the piano as well as his laughter mixed with tears. This is a composer who satisfies musically, pianistically, and spiritually. ${ }^{134}$

\footnotetext{
${ }^{133}$ Barbara Nissman, email message to author, November 1, 2018. Release dates of projects TBD.

${ }^{134}$ Barbara Nissman, "Sergei Prokofiev: A Man Misunderstood," in The Pianist's Craft: Mastering the Works of Great Composers, ed. Richard P. Anderson, (Lanham, Md.: Scarecrow Press, 2012), 199-200.
} 


\section{CHAPTER VI}

\section{INTERVIEW WITH BARBARA NISSMAN}

\section{How do you choose the composers you study and the music you perform? Why is}

the music of the composers you've specialized in so integral to your work as an artist?

I feel blessed that at this point in my life, I have the opportunity to perform and record music that I love and feel passionate about - music with which I feel a strong personal connection and wish to share with the listener.

I confess that the music that speaks to me so strongly is the music of the romantic $19^{\text {th }}$ century (not excluding Beethoven and Schubert) and the early $20^{\text {th }}$ century. This music represents the golden age of piano writing! What all of these composers share is a love of the piano. Because most of them were pianists and performers themselves, they knew how to write for the instrument. Mastering the challenges of virtuosic piano writing and making the composer's language a natural part of my playing is the first step to uncovering the secrets that dwell within the music. And then the next step is having the courage to go "under the notes" and to try and connect with their spirits to make the magic happen and ultimately touch the souls of all who listen. That is the ideal!

Studying so much of the music of Prokofiev, Rachmaninoff, Bartók, Liszt and Ginastera has provided me with an insight into their spirit and their character. These composers have been the inspiration for the educational master class DVD series we are producing. I believe that to deeply understand what they are saying with their music, one must try to understand their humanity. The master class series provides a total picture of these composers, concentrating on their masterworks for the piano and exploring their life using their own words. Liszt and 
Prokofiev are prime examples of so much misunderstanding- not only musically but also personally, politically and spiritually. We hope to create unique educational teaching tools that will be made available to all educational institutions.

All of these $19^{\text {th }}$ and $20^{\text {th }}$ century composers (including Schubert and Beethoven) provide technical challenges for the performer- they make different physical demands on the body as well as diverse emotional demands on the interpreter. The chance to revisit the music of these composers and to keep digging deeper to find musical, emotional and spiritual connections remains the constant challenge. They give purpose to our being, and their music provides us with life-long sustenance. At this point in my life, I am grateful for the joy and the passion that I receive and can share with others. I also am very much aware of the divine element that is present that can make the music soar and transport us to another world - how blessed we are!

\section{What was your experience like studying with pianist György Sándor? What are the most important aspects of piano performance that you learned from him?}

From Sándor, I learned about piano technique and how to identify and solve technical problems. I arrived with a natural instinctive technique using primarily fingers, and Sándor added to that. He helped me to coordinate my entire body into my piano playing, by also making use of the wrist, the arms, the back muscles and taking full advantage of the force of gravity to enhance sound production and produce a warm rich sound. No need to build muscles or strengthen fingers- just a coordination of all the elements working together. Tiredness and tension were not options.

He pushed repertoire and since I learned quickly, this was an advantage. He never worked like some other teachers who obsessed over details nor did he dictate how one should 
play a phrase. The emphasis was always on the larger form and structure, the longer line, the bigger picture, the character of the work, choosing the tempo giusto, with everything shaped within the parameters of good taste and musical intelligence.

In retrospect, I feel fortunate that he let me find my own way and allowed me to discover my own voice. He had no intention to create "clones” of himself. This strong technical foundation has given me the freedom to explore and discover- to develop a wide color range and a warm and a big (not strident!) romantic sound. Sándor provided me with the strong foundation necessary to become a romantic bravura pianist and tackle the large repertoire. There were never any technical exercises given; there was no need for them. Technical problems encountered within the repertoire that was studied were discussed and their difficulties analyzed. An in depth study of all the Chopin Etudes and all the Liszt Etudes provided a firm solid technical foundation. Technique was always discussed within the context of the music and never isolated as a separate exercise. During these 7 years of study with Sándor my solo repertoire grew substantially and my concerto repertoire increased to over 50 piano concertos.

\section{Are there things you wish you would have learned in college that would have} prepared you more for your musical career?

Looking back on my college years, I wish that I could have taken advantage of the recording technology courses now available to music students. Considering my present CD and DVD projects, I would have loved to have learned editing and recording techniques, using audio as well as video, and learned how to make use of the software for musical notation. However this technology was not yet developed and the curriculum was not in place when I was a student. I also wish there had been more time to study languages. Russian and French were the two 
languages used to fulfill my doctoral requirements but my study was confined to reading and translation of texts instead of conversation.

\section{What was it like working with famous conductors such as Eugene Ormandy,} Riccardo Muti, Stanislaw Skrowaczewski and Leonard Slatkin? Did they directly impact your playing or interpretations? If so, how?

Eugene Ormandy:

I grew up listening to the Philadelphia Orchestra conducted by Eugene Ormandy and what a thrill it was to finally meet him and have the opportunity to play for him just before completion of my doctoral studies at the University of Michigan. He was so generous and immediately contacted his European agent to schedule my debut concert tour of the major European capitals. In 1972, I made my American professional debut with Maestro Ormandy and toured with the Philadelphia Orchestra performing Rachmaninoff's Paganini Rhapsody. Hearing the wonderful sounds of the Philadelphia orchestra strings behind me playing Rachmaninoff's lush melodies was an unforgettable experience. It was both inspiring and a little intimidating when Ormandy began telling me stories of playing this piece with the great Rachmaninoff himself. I still remember the moment when we walked on stage together: Ormandy started telling me about the time Rachmaninoff had lost his way in the Rhapsody's rapid sixteenth-note variation. Perhaps he was trying to reassure me that even the great Rachmaninoff was human!!

Riccardo Muti:

I worked with Riccardo Muti, Ormandy's successor to the Philadelphia Orchestra, in Italy when we performed Prokofiev's Second Piano Concerto together with his orchestra in 
Florence. He is such an exciting conductor and even during his early years, he was already such a superb musician and a wonderful collaborator. It was a joy to work with him and perform the music of Prokofiev even though nowadays he conducts much more Scriabin than Prokofiev. $\underline{\text { Stanislaw Skrowaczewski: }}$

It was always a joy for me to work with Maestro Skrowacazewski; he was such a fine musician and conductor and composer. We first met in Munich, early in my career, when I was engaged to perform with the Bayrischer Rundfunk Orchestra a concerto by Mendelssohn. He was such a superb accompanist and there was a mutual respect immediately established between us. After this performance he invited me to make my debut with his orchestra in Minnesota and for those concerts we performed Prokofiev's Second Piano Concerto together. Over the years we had the chance to collaborate on concertos by Chopin (his great love!), Mozart, Liszt, Schumann, Brahms and more Prokofiev. We kept in touch until his death, and I will always appreciate his kind and encouraging words about my playing. It was a joy and a privilege to know him and to make music with him!!

Leonard Slatkin:

Leonard Slatkin in my opinion is one of America's most exciting conductors and remains the ideal exponent for the music of Alberto Ginastera. He captures the rich colors and communicates the visceral energy of Ginastera's music. We have performed together in concert with the symphonies of Chicago, New York, St. Louis, Cleveland and Minnesota. After my New York Philharmonic debut in 1987 with Ginastera's First Piano Concerto, I brought to Slatkin the manuscript of the Popol Vuh, Ginastera's final work that remained incomplete upon his death. This work, originally commissioned by Ormandy and the Philadelphia Orchestra, received its world premiere with Slatkin and the St. Louis Symphony. 


\section{How would you describe your husband's influence on your career and artistry?}

After living and performing in Europe for around ten years, I returned to live in America in 1981. When I was performing a memorial concert for Alberto Ginastera in 1983 at the Cathedral Church of St. John the Divine in New York City, I met the poet Daniel Haberman who had just been appointed the first poet-in-residence at the Cathedral. (He would go on to establish the American Poets' Corner in 1984, America's answer to Westminster Abbey, now housed at the Cathedral.)

We married in 1987 and left New York City in 1989 to settle on a farm in Greenbrier County, West Virginia- a place where we could live together and work within our two separate studios- a sound tight music studio and a peaceful writer's studio where the sounds of the piano would not be heard.

I strongly believe that love and work are the essential ingredients of life. How can one play Rachmaninoff without them! Daniel was the "miracle" and the love of my life. I learned from him what it means to be a "serious" artist. Poets and performers are such different breeds but he made me aware that an artist has a responsibility to developing their talent. Going to West Virginia was all about having the time and the peace and the solitude to go to work - to keep chipping away to go deeper and get a little closer.

It was Daniel who encouraged me with the project to record and perform all of Prokofiev's Piano Sonatas and other major works- something that had not previously been accomplished. He gave me the courage to go forward on my own pathway - to follow my nose wherever that might lead me. And I truly learned from him.

Unfortunately two months after we moved to WV, Daniel was diagnosed with a terminal illness. At that time I cancelled most of my engagements and stopped travelling and touring so 
that we could fight his illness together. Sadly we lost the battle and he passed away two years later in 1991. After his death, one could say that I dropped out of sight. I call this my "Rip van Winkle" period. Of course, I did not stop playing the piano or working at the piano, but I'll admit that it was difficult for me to continue the concert life that I had led before my husband passed away. Sometimes we need the time to step back and question, to explore and rediscover ourselves. Fortunately, with the help of a good friend who took my arm and helped to yank me out of the quicksand into which I was sinking, I began to live once again. I started working again and resumed performing and recording. All of these recordings are special to me - all are journeys of my soul. I feel that now I can go to those deep dark places in the soul without fear, knowing that I will come back to the light. And music helps me to travel there and to share this journey with all who listen.

It was also during this period that I wrote the book, Bartok \& the Piano. When my thenrecord label asked me to record all of Bartok's piano music, I realized this was just the difficult project that was needed to refocus my energies. I searched for a book on his piano music and was not able to find the book that I was looking to read to guide me with this project. That is how Bartok \& the Piano came to be written.

Living on a farm in the mountains of West Virginia has been a great blessing for me. Here I have the peace and quiet to work, to explore, to rediscover and the courage to truly follow my own pathway wherever that might lead. Here I have the time to work to go deeper into the music, always striving to get closer to the composers' intentions and connecting with their spirit. 


\section{Have you recorded newer versions of an already published recording? If so, what has changed? How is the interpretation different?}

It has been a joy to go back and revisit works that I have performed or recorded previously. A recording or performance only represents one interpretation captured in a particular timeframe. Fortunately, we continue to grow and experience and hence, nothing can ever remain the same. When I was preparing the 10-part recital series that I recorded, I had the opportunity to revisit so many of the works I had previously studied as a young student and realized how my perceptions have changed over the years and how much I have grown as an artist and a human being. And for me, every live performance of a work is different- constantly changing!

In general as I get older, I notice a greater freedom- more willingness to take risks perhaps a more serious commitment to the composer and his music. Several years ago I recorded the Sixth Sonata of Prokofiev for one of the recital CDs and realized how different this performance was many years after the first release of my complete Prokofiev Sonata recordings. Much more attention was paid to defining the structure and its boundaries and I was not so frightened by the extremes of this masterwork. We aspire to have the courage to play fearlessly but always need to try and balance freedom with control. I can't say which of these recordings I prefer but certainly they are very different from each other.

And the challenge never gets easier - perhaps that's why playing the piano is so addictive. To quote Rachmaninoff : "Music is enough for a lifetime but a lifetime is not enough for music.” 


\section{What advice could you give to pianists to develop piano technique and}

\section{interpretation?}

It is important to always remember that playing the piano should never be about strengthening muscles; it's about avoiding tension and coordinating all the elements at our disposal, always used in perfect harmony. As soon as there is any trace of pain or tension, we should stop and examine what is in tension and try to alleviate the problem. Playing the piano is not like swimming laps to build up endurance and strength. If you feel any trace of tiredness or pain- stop! That is the fire alarm, the red light that says: you are doing something wrong so check your hands and arms and try to figure out what exactly is in tension- what is causing the problem. Playing the piano should be done with ease and a natural coordination. The expression, "no pain, no gain” does not apply to piano-playing.

Also what I find frequently lacking with so many artists is the sheer joy of playing the piano and the sharing of this joy with the listener. It sounds obvious but if you are not enjoying yourself, then most likely, the audience isn't either. So after all the groundwork has been done: stop worrying about the notes and try to experience the joy and the passion of this great piano music.

Playing the piano should not be about perfection or achieving a note-perfect performance. That's what competitions are about. Becoming an artist and making music involves much more than that. It involves your total being and total commitment.

Regarding interpretation: It is important to develop your own personal voice; it is not sufficient to just imitate the playing of someone else or a performance that you might have heard on you-tube. The deeper you go into the music, the more personal will be your connection with the composer. Study the score and try to go "under the notes" to understand what the composer 
is saying and understand how the work is put together. Understanding form and structure is essential, and it is the performer's responsibility to clarify the form for the listener. Read as much as you can about the composer - try to understand him as a human being. We need to go beyond the surface of the notes to get closer to the composer's intentions and his musical spirit. Live with the music! Make it your own and allow the music to come to you! And it will. I like to think that we are being led by the spirit of the composer as to where "he" wants the music to go. Ideally what we are trying to bring to the listener is a personal statement from the composer straight to the hearts of those who listen. The performer acts as the middle-man- the conduit who gets out of the way so as not to interfere with that direct line of communication. Every time we perform, we should strive to recreate or come as close as we possibly can to what the composer might have imagined at that very moment of his own creation. And that takes boldness and courage! It requires using our artistic intuition- taking that "leap of faith" to go forward! It's a lifetime's work that takes time, patience, talent and commitment and a true passion for what we are doing!

\section{What advice would you give to pianists developing a performing career?}

Work as hard as possible but always proceed with love and joy in your heart. Playing the piano should not be a job-it should be a great passion and how fortunate you are to have found something you are passionate about. It guides us to live a fulfilling life.

Take advantage of every opportunity to share what you do. A concert at your local church can be just as meaningful as a Carnegie Hall appearance. You never know whose soul you will be able to reach and touch and perhaps make a huge difference in someone's life. And that is what music-making is all about! 


\section{Are there any further thoughts for pianists or words about your work you would}

\section{like to add?}

I am grateful now to be in a "rebirthing" period in my life and feel so blessed to be able to work and pursue the projects and the music for which I feel a true passion. At this point in my life, it is no longer about making my own way with my career but more about leaving something behind for the next generation. That is why I have started my own record label, Three Oranges Recordings, and gathered in one place the body of work that has been produced and the CDs we continue to produce every year. I have also started producing an educational DVD series, a unique teaching tool to correct so much of the misunderstanding that has surrounded the composers I have loved and admired and lived with for so many years. The Three Oranges Foundation has just been established to provide the necessary funding to build and maintain this educational legacy.

As I get older, I am truly aware of the "divine” element in my life- the hand of God in everything I do, not only at the piano but also in my personal interactions with people who cross my path. Each of us has a mission to fulfill and how blessed we are when we feel that we are doing what we are meant to do in this life. I strongly believe that we are guided from above to fulfill our dreams -it cannot be only ourselves who are responsible for our talent or for making things happen - there is a "divine" element at work here as well.

In 1976, I was diagnosed with a Stage 3 melanoma, a serious form of skin cancer. At that

time, I underwent surgery and the operation excised a portion of my back removing the layer of skin right down to the muscle; I had to undergo extensive skin grafts to cover the large hole in my back. For me the true miracle is that I am still able at my age and with my past medical history, to play with strength the large romantic repertoire. In fact, I feel my playing is stronger 
than it was in my younger years. It is not only me that is responsible for this medical healing. Call it divine intervention! I strongly believe that with the help of something much higher than all of us, I was able to survive and now continue to do what I am doing.

I shared this piece of my history with you because I do believe that every one of us has a "mission" in this life. It's not only a musical mission but it involves the people with whom we cross paths. Each one of us has the power to make a difference and we have the responsibility to try our best to live a "well-lived life" - touching souls along the way.

How grateful I am for the inspiring power of music. My love of the piano has always been my life-line. And I am looking forward to the next chapter!!

Barbara Nissman, Lewisburg, WV October 14, 2018.

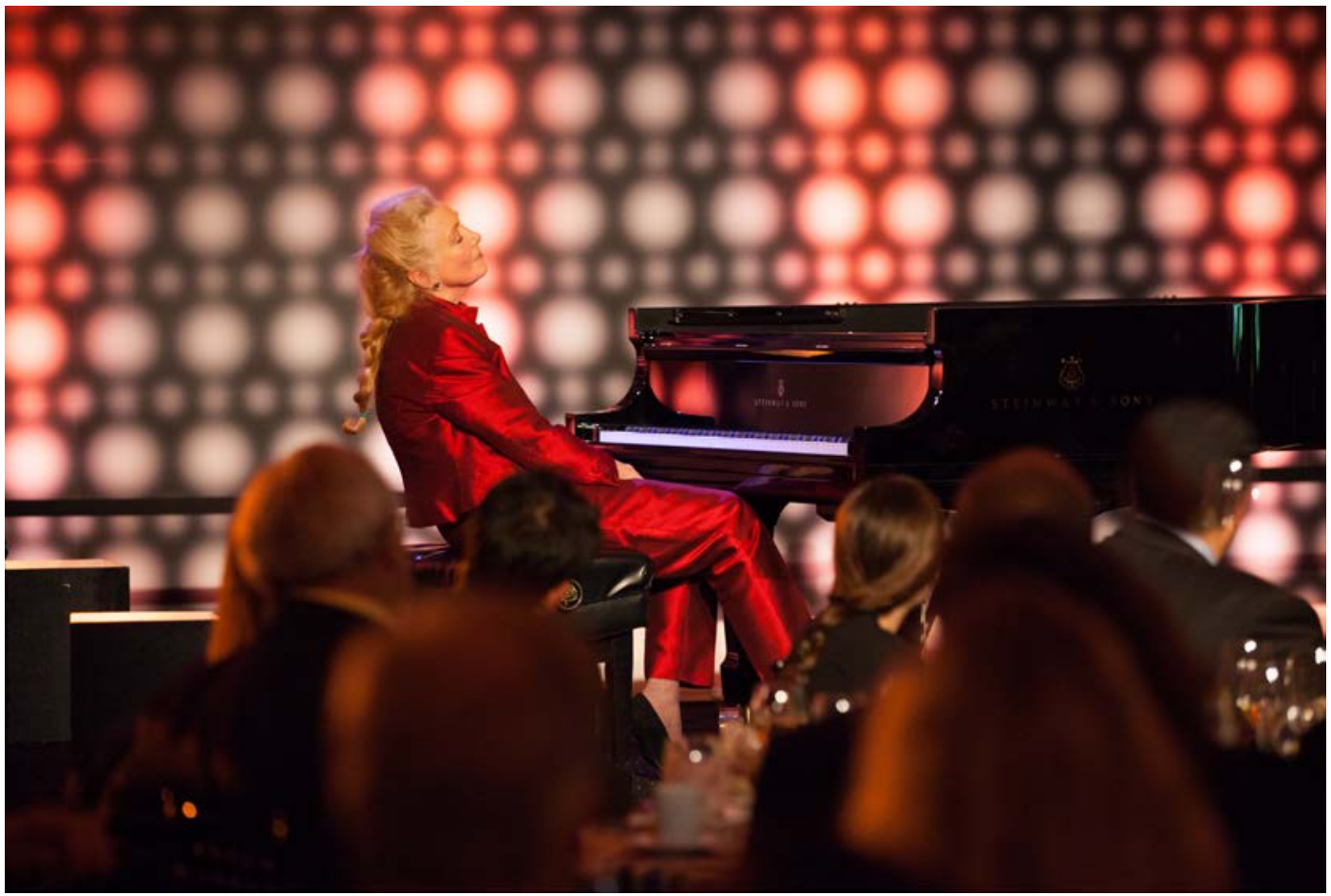

Figure 14. Barbara Nissman performing at the gala ceremony honoring Dr. Arthur J. Ammann, the founder of Global Strategies. Concert held at de Young Museum in San Francisco, California on November $1^{\text {st }}, 2014$. 


\section{CHAPTER VII}

\section{CONCLUSION}

Referred to as "one of the last pianists in the grand Romantic tradition of Liszt, Rachmaninoff and Rubinstein," ${ }^{\text {"35 }}$ Barbara Nissman is considered one of the finest concert pianists around the world. Her numerous performances, recordings, writings, lectures, and master classes make her a much admired pianist and one of the leading musicians of our time.

Barbara Nissman has performed with worldwide symphony orchestras and has worked closely with legendary conductors and musicians. She has toured throughout the United States, Europe, Russia, New Zealand, the Far East, and South America. Critics worldwide highly praise her performances and recordings highlighting her deep understanding of the music, her bravura and her thoughtfulness, lyricism, and imagery.

Nissman's writings, lectures and DVDs provide not only an in-depth examination of foremost composers and their piano music, but also offer a unique performer’s perspective, providing insightful guidelines for pianists and other musicians studying these extraordinary composers. In addition, her comprehensive work helps to clarify the many misconceptions and stereotypes that have shadowed some of the great composers of the $19^{\text {th }}$ and $20^{\text {th }}$ centuries.

With the establishment of her record label Three Oranges Recordings and her Three Oranges Foundation, Nissman intends to reach more diverse audiences and make classical music accessible to everyone. This personal mission can be seen not only in her educational DVD series, writings, and lectures but it is also shown in her frequent master classes, fundraising concerts and outreach performances.

\footnotetext{
${ }^{135}$ Barbara Nissman, accessed November 4, 2018, https://www.barbaranissman.com/.
} 
This research paper provides the first overview of the life and work of Barbara Nissman, bringing a more complete awareness of her contributions to an even wider audience. As a pianist who followed a unique path to sharing her artistry, Nissman has built a multi-faceted career without the typical exposure from international competitions which in itself offers inspiration for musicians looking to achieve their own professional goals. Nissman's experience and advice is broadly applicable as she reminds not just pianists but all musicians of the true artistic responsibility of the performer. She inspires listeners to explore the music of her much-admired composers and encourages future generations of pianists and other musicians to expand their own artistic journeys. 


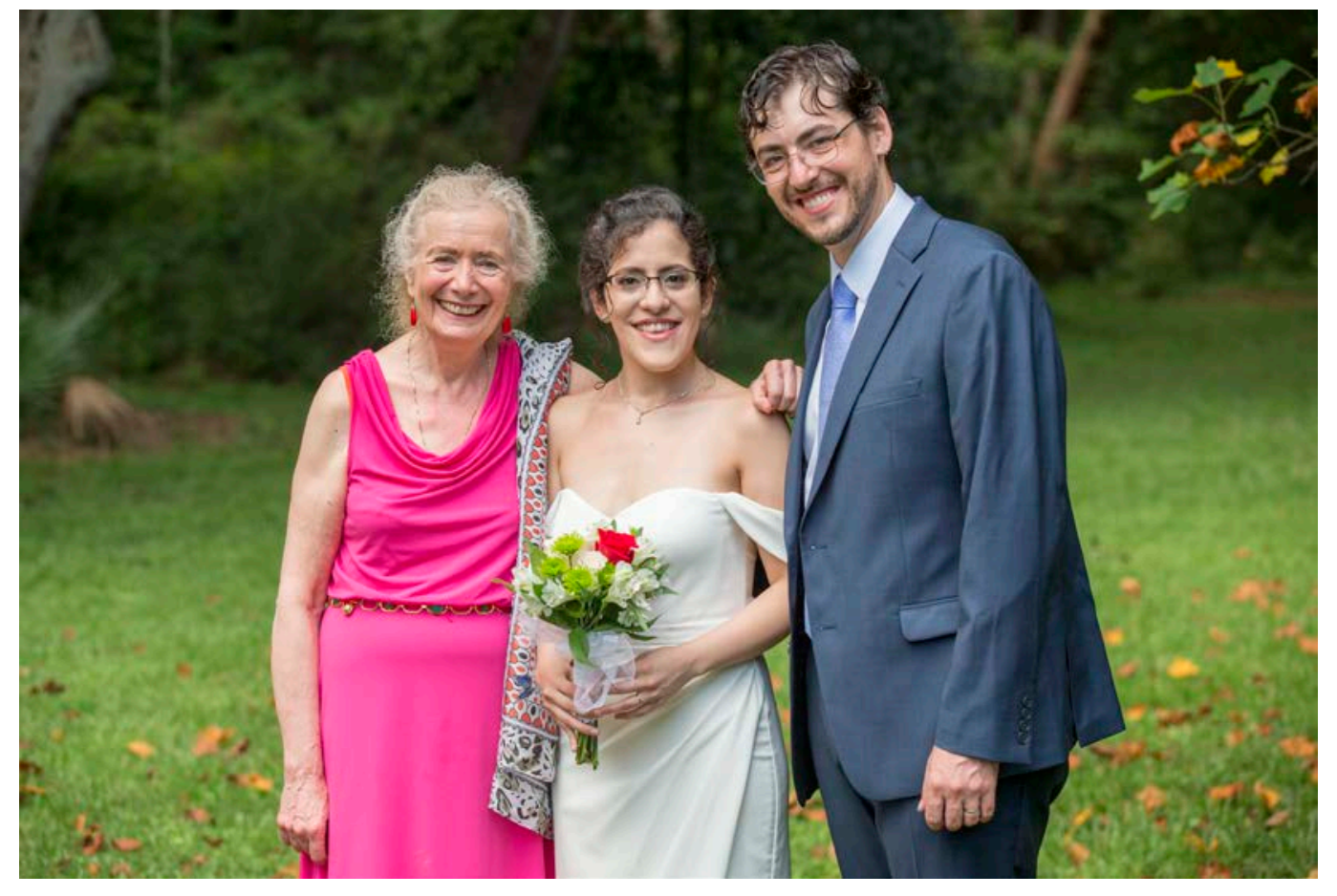

Figure 15. Barbara Nissman at my wedding in Charleston, SC on August 11 ${ }^{\text {th }}, 2018$. 


\section{SELECTED DISCOGRAPHY}

\section{COMPOSER SERIES}

Béla Bartók

- Folk Music \& More!: Music of Béla Bartók. CD. Three Oranges Recordings, 2014.

- Reissue of Bartók by Nissman (CD) published by Pierian Recording Society, 2003.

Repertoire:

First Recording of Unpublished Sonata (1898)

Two Elegies Op. 8b

Improvisations on Hungarian Peasant Songs Op. 20

Four Dirges Op. 9a

Rhapsody Op. 1

Ludwig van Beethoven

- Beethoven: The Late Sonatas. CD. Three Oranges Recordings, 2017.

Repertoire:

Sonata No. 30 in E Major Op. 109

Sonata No. 31 in Ab Major Op. 110

Sonata No. 32 in C Minor Op. 111

- Visions: Sonatas of Beethoven, Volume I. CD. Three Oranges Recordings, 2014.

- Reissue of Beethoven by Nissman, Volume 1 (CD) published by Pierian Recording Society, 2003.

Repertoire:

Sonata Op. 53 No. 21 (Waldstein)

Sonata Op. 27 No. 2 (Moonlight)

Sonata Op. 57 No. 23 (Appassionata)

Rondo à Capriccio Op. 129 (Rage over a Lost Penny)

Johannes Brahms

- A Noble Heart: Music of Johannes Brahms. CD. Three Oranges Recordings, 2014.

- Reissue of Brahms by Nissman (CD) published by Pierian Recording Society, 2005.

Repertoire:

Piano Sonata No.2 in F-sharp Minor

Scherzo in E-flat Minor

Eight Piano Pieces Op. 76

Two Rhapsodies Op. 79 No. 1 \& 2

Two Waltzes Op. 39 No. 2 \& 15 
Frédéric Chopin

- Chopin: The Nocturnes, Barcarolle \& Polonaise in F\# minor. CD. 2 vols. Three Oranges Recordings, 2017.

Repertoire:

Nocturnes: Op. 9 No. 1-3

Op. 15 No. $1-3$

Op. 27 No. $1-2$

Op. 32 No. $1-2$

Op. 37 No. $1-2$

Op. 48 No. $1-2$

Op. 55 No. $1-2$

Op. 62 No. $1-2$

Op. 72 No. 1

Op. posthumous in C-sharp Minor

Op. posthumous in C Minor

Barcarolle Op. 60 in F-sharp Major

Polonaise Op. 44 in F-sharp Minor

- Chopin! Sonata in B minor, Berceuse \& Four Scherzi. CD. Three Oranges

Recordings, 2017.

Repertoire:

Sonata No. 3 in B minor Op. 58

Berceuse in D-flat Major Op. 57

Four Scherzi Op. 20, 31, 39 \& 54

- Longing... Music of Frédéric Chopin. CD. Three Oranges Recordings, 2014.

- Reissue of Chopin by Nissman (CD) published by Pierian Recording Society, 2003.

Repertoire:

Polonaise-Fantasy Op. 61

Three Etudes: Op. 25 No. 1 (Harp), Op. 10 No. 3, Op. 10 No. 12 (Revolutionary)

Fantasy in F minor Op. 49

Three Nocturnes: Op. 9 No. 2, Op. 48 No. 1, Op. 27 No. 2

Scherzo No. 3 Op. 39

Fantasy-Impromptu Op. 66

Polonaise Op. 53 (Heroic)

Waltz Op. 34 No. 1 (Valse Brillante)

Alberto Ginastera

- Alberto Ginastera: The Complete Music for Piano \& Piano Chamber Ensembles.

CD. 2 vols. Three Oranges Recordings, 2014. 
- Reissue of Alberto Ginastera: The Complete Music for Piano \& Piano Chamber Ensembles (CD. 2 vols.) published by Pierian Recording Society, 2001.

- The Pierian 2001 recording is a reissue of Criolla - Alberto Ginastera: The Complete Music for Piano \& Piano Chamber Ensembles, Volume 1 (CD) published by Newport Classic, 1991 and Malambo - Alberto Ginastera: The Complete Music for Piano \& Piano Chamber Ensembles, Volume 2 (CD) published by Newport Classic, 1992.

Performers:

Barbara Nissman, piano

Aurora Natola-Ginastera, cello

Ruben Gonzalez, violin

The Laurentian String Quartet: Sung Rai Sohn \& Larry Watson, violins; Joel Rudin, viola; Rolf Gilstein, cello (quartet in residence at Sarah Lawrence College)

Repertoire:

- Disc 1:

Sonata No. 1 Op. 22

Sonata No. 2 Op. 53

Sonata No. 3 Op. 55

Danzas Argentinas Op. 2

Tres Piezas Op. 6

Malambo Op. 7

Doce Preludios Americanos Op. 12

Suite de Danzas Criollas Op. 15

Rondó sobre Temas Infantiles Argentinos Op. 19

- Disc 2:

Pampeana No. 1 Op. 16 (Rhapsody for violin \& piano)

Milonga from "Dos Canciones” Op. 3

Tres Danzas from "Estancia” Op. 8

Toccata by Zipoli (trans. by Ginastera)

Quintet for Piano \& String Quartet Op. 25

Pampeana No. 2 Op. 21 (Rhapsody for cello \& piano)

Sonata for Cello \& Piano Op. 49

- Nissman Plays Ginastera: The Three Piano Concertos. World premiere recordings of Concierto Argentino and Piano Concerto No. 2 Op. 39 in its original version. CD. Pierian Recording Society, 2012.

Performers:

Barbara Nissman, piano

Kenneth Kiesler, conductor

University of Michigan Symphony Orchestra 
Repertoire:

Concierto Argentino

Piano Concerto No. 1 Op. 28

Piano Concerto No. 2 Op. 39 (original version)

- Alberto Ginastera: Piano Music. LP. Desto Records, 1984.

- Reissue of Barbara Nissman plays Ginastera (LP) published by CBS Records, 1981. This recording was later published in CD format by Globe Records in 1988.

Repertoire:

Sonata No. 1 Op. 22

Tres Danzas Argentinas Op. 2

Doce Preludios Americanos Op. 12

Suite de Danzas Criollas Op. 15

Rondó sobre Temas Infantiles Argentinos Op. 19

Franz Liszt

- Liszt: The Transcendentals. CD. Three Oranges Recordings, 2017.

Repertoire:

Funérailles (from Harmonies poétiques et religieuses)

Valse Oubliée No. 1 in F\# minor

12 Transcendental Studies (1852 version)

- Superstar!: Music of Franz Liszt. CD. Three Oranges Recordings, 2014.

- $\quad$ Reissue of Liszt by Nissman (CD) published by Pierian Recording Society, 2002.

Repertoire:

Sonata in B minor

Spanish Rhapsody

Consolation No. 3 in D-flat

Six Paganini Etudes 1-6

- Franz Liszt: The Sonata in B Minor and Other Works for Solo Piano. CD. Newport Classic, 1993.

- Franz Liszt: 6 Paganini Etudes; 3 Concert Etudes; Rhapsodie Espagnole. LP. Globe Records, 1982.

Sergei Prokofiev

- Prokofiev by Nissman: The Complete Piano Sonatas. CD. 3 vols. Includes the two versions of the Fifth Sonata and the Tenth Sonata fragment. Three Oranges Recordings, 2014. 
- Reissue of Prokofiev by Nissman: The Complete Piano Sonatas (CD. 3 vols.) published by Pierian Recording Society, 2001.

- The Pierian 2001 recording is a reissue of Sergei Prokofiev: Complete Piano Sonatas - Volume 1, 2 \& 3 (released in 3 separate CDs) published by Newport Classic, 1989.

Repertoire:

- Disc 1:

Sonata No. 1 Op. 1

Sonata No. 2 Op. 14

Sonata No. 3 Op. 28

Sonata No. 4 Op. 29

Sonata No. 5 Op. 38 (First Version)

Sonata No. 5 Op. 38/135 (Second Version)

- Disc 2:

Sonata No. 6 Op. 82

Sonata No. 7 Op. 83

Sonata No. 8 Op. 84

- Disc 3:

Sonata No. 9 Op. 103

Sonata No. 10 Op. 137

Four Pieces Op. 4

Toccata Op. 11

Sarcasms Op. 17

Visions Fugitives Op. 22

Sergei Rachmaninoff

- Love \& Loss: Music of Rachmaninoff, Volume II. CD. Three Oranges Recordings, 2014.

- Reissue of Rachmaninoff by Nissman: Volume 2 (CD) published by Pierian Recording Society, 2007.

Repertoire:

Etudes-Tableaux: Op. 33 No. 1-8, Op. 39 No. 1-9

Kreisler: "Liebesleid" (arr. by Rachmaninoff)

Rimsky-Korsakov: "Flight of the Bumblebee" (arr. By Rachmaninoff)

Vocalise Op. 34 No. 14 (trans. by Earl Wild)

- Love \& Loss: Music of Rachmaninoff, Volume I. CD. Three Oranges Recordings, 2014.

- Reissue of Rachmaninoff by Nissman: Volume 1 (CD) published by Pierian Recording Society, 2006. 
Repertoire:

Prelude Op. 3 No. 2 in C-sharp Minor

Preludes Op. 23 No. 1-10

Preludes Op. 32 No. 1-13

\section{Robert Schumann}

- $\quad$ The Storyteller: Music of Robert Schumann. CD. Three Oranges Recordings, 2014.

- Reissue of Schumann by Nissman (CD) published by Pierian Recording Society, 2005.

Repertoire:

Fantasy Op. 17

Toccata Op. 7

Kreisleriana Op. 16

Arabesque Op. 18

Träumerei (from Kinderszenen) 


\section{RECITAL SERIES}

- Fireworks!. CD. Three Oranges Recordings, 2014.

Repertoire:

D. Scarlatti: Sonata L. 38/K. 57, Sonata L. 135/K. 57, Sonata L. 465/K. 96

J. Brahms: Sonata No. 3 Op. 5 in F minor

C. Debussy: Masques, La fille aux cheveux de lin (from Preludes, Book I), La soirée dans Grenade (from Estampes), Feux d'artifice (from Preludes, Book II)

F. Liszt: Hungarian Rhapsody No. 2

- Out of Doors. CD. Three Oranges Recordings, 2014.

Repertoire:

B. Bartók: Out of Doors

F. Schubert: Four Impromptus Op. 90

F. Chopin: Nocturne Op. 32 No. 1

S. Rachmaninoff: Three Preludes (Op. 32 No. 12, Op. 32 No. 5, Op. 3 No. 2) and Three Etudes-Tableaux (Op. 39 No. 1, 2 \& 6)

J. N. Hummel: Rondo Op. 11

S. Rachmaninoff-Mendelssohn: Scherzo (from A Midsummer Night's Dream)

S. Prokofiev: Gavotte (from Symphony No. 1)

- Fascinating Rhythms! CD. Three Oranges Recordings, 2014.

- Reissue of Recital Favorites by Nissman Volume 8 (CD) published by Pierian Recording Society, 2011.

Repertoire:

S. Prokofiev: Sonata No. 1 Op. 1

R. Schumann: Sonata No. 1 Op. 11

F. Chopin: Ballade No. 4 Op. 52

B. Lees: Visages (written in 2009 and dedicated to Barbara Nissman)

I. Albéniz: Navarra

A. Ginastera: Sonata No. 1 Op. 22

G. Gershwin: 3 Preludes, No. 2

- $\quad$ Not TOO serious... CD. Three Oranges Recordings, 2014.

- Reissue of Recital Favorites by Nissman Volume 7 (CD) published by Pierian Recording Society, 2011. 
Repertoire:

L.v. Beethoven: 33 Variations on a Waltz Them by Diabelli Op. 120

B. Bartók: Two Rumanian Dances Op. 8a

F. Liszt: "Ricordanza" from Twelve Transcendental Etudes

S. Prokofiev: Prelude Op. 12 No. 7 and March Op. 33 No. 1 from the opera "The Love for Three Oranges”

- Romantic Tales. CD. Three Oranges Recordings, 2014.

- Reissue of Recital Favorites by Nissman Volume 6 (CD) published by Pierian Recording Society, 2011.

Repertoire:

F. Chopin: Ballade No. 1 Op. 23

M. Ravel: Gaspard de la Nuit

D. Buxtehude: Organ Prelude \& Fugue in D minor (arr. by Prokofiev)

S. Prokofiev: Old Grandmother's Tales Op. 31

A. Scriabin: Sonata No. 5 Op. 53

F. Mendelssohn: Etude Op. 104 No. 2

R. Schumann: Sonata No. 2 Op. 22

S. Rachmaninoff: Prelude Op. 23 No. 10.

- $\quad$ Love \& War. CD. Three Oranges Recordings, 2014.

- Reissue of Recital Favorites by Nissman Volume 5 (CD) published by Pierian Recording Society, 2010.

Repertoire:

F. Chopin: Andante Spianato \& Grande Polonaise Brillante Op. 22

S. Prokofiev: Sonata No. 6 Op. 82

F. Liszt: Three Concert Etudes (Il Lamento, La Leggierezza and Un Sospiro)

B. Lees: Odyssey No. 1

B. Bartók: Allegro Barbaro

F. Liszt: Liebestraum No. 3

- Journeys of the Soul. CD. Three Oranges Recordings, 2014.

- Reissue of Recital Favorites by Nissman Volume 4 (CD) published by Pierian Recording Society, 2009.

Repertoire:

J.S. Bach: Italian Concerto BWV 971 in F Major

M. Ravel: Sonatine for Piano in F-sharp Minor

F. Liszt: Sonata in B Minor

A. Scriabin: Etude Op. 2 No. 1, Op. 8 No. 10, Op. 42 No. 5 and Nocturne for the left-hand alone Op. 9 No. 2

M. Balakirev: Islamey. 
- Triumph! CD. Three Oranges Recordings, 2014.

- Reissue of Recital Favorites by Nissman Volume 3 (CD) published by Pierian Recording Society, 2009.

Repertoire:

J.S. Bach: Organ Prelude in A Minor BWV 543 (arr. by F. Liszt)

L.v. Beethoven: Sonata No. 29 Op. 106 "Hammerklavier;"

F. Liszt: Transcendental Etudes (Harmonies du Soir, Feux Follets and Chasse

Neige) and Consolation No. 3 in D-flat Major

S. Prokofiev: Suggestion Diabolique from Four Piano Pieces Op. 4

- Glory in the Highest! CD. Three Oranges Recordings, 2014.

- Reissue of Recital Favorites by Nissman Volume 2 (CD) published by Pierian Recording Society, 2008.

Repertoire:

J.S. Bach: Toccata, Adagio \& Fugue BWV 564 in C Major (arr. by F. Busoni)

S. Barber: Nocturne Op. 33

C. Franck: Prelude, Chorale \& Fugue

L.v. Beethoven: Sonata No. 21 Op. 53 "Waldstein"

E. Granados: The Maiden \& the Nightingale from Goyescas Op. 11

A. Ginastera: Danzas Argentinas Op. 2 No. 2 \& 3

C. Debussy: Clair de Lune from Suite Bergamasque

- Dramatic Visions. CD. Three Oranges Recordings, 2014.

- Reissue of Recital Favorites by Nissman Volume 1 (CD) published by Pierian Recording Society, 2008.

Repertoire:

L.v. Beethoven: Sonata No. 8 Op. 13 "Pathétique"

S. Prokofiev: Visions Fugitives Op. 22 No. 1, 3, 8, 9 and Sonata No. 3 Op. 28

F. Schubert: Wanderer Fantasy D. 760

R. Wagner: Isolde's Liebestod from Tristan und Isolde (arr. by F. Liszt)

F. Liszt: Mephisto Waltz No. 1 S. 514

F. Chopin: Nocturne Op. 27 No. 2 


\section{DVD SERIES}

- Franz Liszt: Portrait of the Man \& his Masterwork - The Sonata in B minor. DVD. 2 vols. Three Oranges Recordings, 2016.

Performers:

Barbara Nissman (creator and performer)

Michael York as the voice of Franz Liszt

Other voices: Pete Ballard, Jon Cavendish, Miles Chapin, Harry Connick Jr., Rebecca de Mornay, David Dubal, Barbara Feldon, Rosemary Harris, Don Henley, Manfred Honeck, Billy Joel, Stuart Margolin, Bill McGlaughin, Kermit Medsker, Dennis Rooney, Peter Schickele, John Schuck, Anna Singer and Leonard Slatkin.

- Disc I: Portrait of Franz Liszt

- Disc II: The Sonata in B Minor

Part 1: A Master Class with Barbara Nissman

Part 2: Concert Performance of the B minor Sonata

- Alberto Ginastera: A Man of Latin America. DVD. Scheduled for release in 2019.

Performers:

Barbara Nissman (creator and performer)

Includes interviews with:

Alberto Ginastera

Aurora Nátola-Ginastera (Ginastera’s wife)

Georgina Ginastera (Ginastera’s daughter)

Leonard Slatkin (conductor)

Marlos Nobre (composer)

Keith Emerson (from Emerson, Lake \& Palmer rock band)

Chick Corea (jazz pianist)

- $\quad$ Sergei Prokofiev. DVD. Work in progress.

Performer:

Barbara Nissman (creator and performer) 


\section{SELECTED WRITINGS AND EDITIONS}

Béla Bartók

- Bartók and the Piano: A Performer's View. Author of book and performer of CD companion. Published by Scarecrow Press in 2002.

- " “Symposium: Beyond Nationality." Contributor of article published in International Piano magazine (UK). March-April 2014 issue.

Other contributors featured in article: Vladimir Ashkenazy, Peter Donohoe, Peter Frankl, Jenö Jandó, Zoltán Kocsis and Jeremy Siepmann.

Alberto Ginastera

- Piano Concerto No. 2 Op. 39. Editor of Critical Edition (score) published by Boosey \& Hawkes in 2016.

- $\quad$ Piano Sonata No. 2 Op. 53, Piano Sonata No. 3 Op. 54 and Concierto Argentino. Contributing editor of these scores - all published by Boosey \& Hawkes.

- "Remembering Alberto Ginastera.” Author of book chapter included in The Pianist's Craft 2: Mastering the Works of More Great Composers. Book edited by Richard P. Anderson. Published by Rowman \& Littlefield in 2015.

- "Remembering Alberto Ginastera - A Centenary Tribute.” Author of article published in Musical Opinion Quarterly(UK). April-June 2016 issue.

Sergei Prokofiev

- "When Gershwin met Prokofiev.” Author of article published in Piano Today (UK). Cover story of Winter 2005 issue. This article was later adapted for Three Oranges Journal (January 2016).

- “Sergei Prokofiev: A Man Misunderstood.” Author of book chapter included in The Pianist's Craft: Mastering the Works of Great Composers. Book edited by Richard P. Anderson. Published by Scarecrow Press in 2012.

- “Symposium: Shakespearean Sage or Soviet Court Jester?” Contributor of article published in International Piano magazine (UK). July-August 2013 issue.

Other contributors featured in article: Vladimir Ashkenazy, Murray McLachlan, Frederic Chiu, Boris Berman and Jeremy Siepmann.

- “The Many Faces of Prokofiev: As seen through his Piano Concertos.” Author of article published in Three Oranges Journal. November 2002 issue.

Other articles written by Nissman about the music of Bartók, Ginastera, Liszt and Prokofiev have been published in numerous magazines: Musical Opinion (UK), Piano (UK), Musical Times (UK), Keyboard Classics, Keynote and Piano Today.

Additional writings on pianism; performance; recordings; discussions on the piano music of various composers (Rachmaninoff, Chopin, Brahms, Liszt, Ginastera and Prokofiev, among others); and her own artistic experiences are available on her blog: https://threeorangesrecordings.com/blog. 


\section{BIBLIOGRAPHY}

Ginastera, Alberto. Piano Concerto No. 2, Op. 39. Edited by Barbara Nissman. New York: Boosey \& Hawkes, 2016.

Hamilton, Kenneth, ed. The Cambridge Companion to Liszt. Cambridge Companions to Music. Cambridge: Cambridge University Press, 2005.

Nissman, Barbara. Bartók and the Piano: A Performer's View. Lanham, Md.: Scarecrow Press, Inc., 2002.

— . "Sergei Prokofiev: A Man Misunderstood.” In The Pianist's Craft: Mastering the Works of Great Composers, edited by Richard P. Anderson, 189-200. Lanham, Md.: Scarecrow Press, Inc., 2012.

—_. "Remembering Alberto Ginastera." In The Pianist's Craft 2: Mastering the Works of More Great Composers, edited by Richard P. Anderson, 118-134. Lanham, Md.: Rowman \& Littlefield, 2015.

_ . "Remembering Alberto Ginastera - A Centenary Tribute.” Musical Opinion Quarterly, no. 1507 (April-June 2016): 18-20.

—. Liszt: The Transcendentals. CD. Three Oranges Recordings, 2017.

—. Prokofiev by Nissman. CD. 3 vols. Pierian Recording Society, 2001.

- Franz Liszt: Portrait of the Man \& his Masterwork - The Sonata in B minor. DVD. 2 vols. Three Oranges Recordings, 2016.

—. Barbara Nissman. https://www.barbaranissman.com/.

_. Piano Connections with Barbara (blog). Three Oranges Recordings. https://threeorangesrecordings.com/blog.

—. Curriculum vitae.

Nissman, Barbara, Aurora Natola-Ginastera, Ruben Gonzalez, and The Laurentian String Quartet. Alberto Ginastera: The Complete Music for Piano \& Piano Chamber Ensemble. CD. 2 vols. Pierian, 2001.

Nissman, Barbara, Kenneth Kiesler, and University of Michigan Symphony Orchestra. Nissman Plays Ginastera: The Three Piano Concertos. CD. Pierian Recording Society, 2012. 
Nissman, Barbara, Vladimir Ashkenazy, Murray McLachlan, Frederic Chiu, Boris Berman, and Jeremy Siepmann. "Symposium: Shakespearean Sage or Soviet Court Jester?” International Piano, no. 20 (July-August 2013): 29-33.

Nissman, Barbara, Vladimir Ashkenazy, Peter Donohoe, Peter Frankl, Jenö Jandó, Zoltán Kocsis, and Jeremy Siepmann. "Symposium: Beyond Nationality.” International Piano, no. 24 (March-April 2014): 47-51.

Robinson, Harlow. Sergei Prokofiev: A Biography. Boston: Northeastern University Press, 2002.

Schwartz-Kates, Deborah. Alberto Ginastera: A Research and Information Guide. Routledge Music Bibliographies. New York: Routledge, 2010.

Ujfalussy, József. Béla Bartók. Boston: Crescendo Publishing Company, 1972.

Interview

Barbara Nissman: $\quad$ October 14, 2018, submitted written answers. 